\title{
Formation and growth of atmospheric nanoparticles in the eastern Mediterranean: results from long-term measurements and process simulations
}

\author{
Nikos Kalivitis $^{1,2}$, Veli-Matti Kerminen ${ }^{3}$, Giorgos Kouvarakis ${ }^{1}$, Iasonas Stavroulas ${ }^{1,4,5}$, Evaggelia Tzitzikalaki ${ }^{1}$, \\ Panayiotis Kalkavouras $^{1,5}$, Nikos Daskalakis ${ }^{1,6}$, Stelios Myriokefalitakis ${ }^{5,7}$, Aikaterini Bougiatioti ${ }^{5}$, \\ Hanna E. Manninen ${ }^{3,8}$, Pontus Roldin ${ }^{9}$, Tuukka Petäjä ${ }^{3}$, Michael Boy ${ }^{3}$, Markku Kulmala ${ }^{3}$, Maria Kanakidou ${ }^{1}$, and \\ Nikolaos Mihalopoulos ${ }^{1,5}$ \\ ${ }^{1}$ Environmental Chemical Processes Laboratory, Department of Chemistry, University of Crete, 70013, Heraklion, Greece \\ ${ }^{2}$ Institute for Astronomy, Astrophysics, Space Applications and Remote Sensing, National Observatory of Athens, \\ I. Metaxa \& Vas. Pavlou, 15236 Palea Penteli, Greece \\ ${ }^{3}$ Institute for Atmospheric and Earth System Research/Physics, Faculty of Science, University of Helsinki, 00014 Helsinki, \\ Finland \\ ${ }^{4}$ Energy, Environment and Water Research Center, The Cyprus Institute, Nicosia 2121, Cyprus \\ ${ }^{5}$ Institute for Environmental Research \& Sustainable Development, National Observatory of Athens, \\ I. Metaxa \& Vas. Pavlou, 15236 Palea Penteli, Greece \\ ${ }^{6}$ Laboratory for Modeling and Observation of the Earth System (LAMOS), Institute of Environmental Physics (IUP), \\ University of Bremen, Bremen, Germany \\ ${ }^{7}$ Institute for Marine and Atmospheric Research (IMAU), Utrecht, the Netherlands \\ ${ }^{8}$ Experimental Physics Department, CERN, 1211 Geneva, Switzerland \\ ${ }^{9}$ Division of Nuclear Physics, Department of Physics, Lund University, P.O.Box 118, 22100 Lund, Sweden
}

Correspondence: Nikos Kalivitis (nkalivitis@uoc.gr) and Nikolaos Mihalopoulos (nmihalo@ noa.gr)

Received: 3 March 2018 - Discussion started: 11 April 2018

Revised: 17 December 2018 - Accepted: 24 January 2019 - Published: 1 March 2019

\begin{abstract}
Atmospheric new particle formation (NPF) is a common phenomenon all over the world. In this study we present the longest time series of NPF records in the eastern Mediterranean region by analyzing 10 years of aerosol number size distribution data obtained with a mobility particle sizer. The measurements were performed at the Finokalia environmental research station on Crete, Greece, during the period June 2008-June 2018. We found that NPF took place on $27 \%$ of the available days, undefined days were $23 \%$ and non-event days $50 \%$. NPF is more frequent in April and May probably due to the terrestrial biogenic activity and is less frequent in August. Throughout the period under study, nucleation was observed also during the night. Nucleation mode particles had the highest concentration in winter and early spring, mainly because of the minimum sinks, and their average contribution to the total particle number concentration was $8 \%$. Nucleation mode particle concentra-
\end{abstract}

tions were low outside periods of active NPF and growth, so there are hardly any other local sources of sub- $25 \mathrm{~nm}$ particles. Additional atmospheric ion size distribution data simultaneously collected for more than 2 years were also analyzed. Classification of NPF events based on ion spectrometer measurements differed from the corresponding classification based on a mobility spectrometer, possibly indicating a different representation of local and regional NPF events between these two measurement data sets. We used the MALTE-Box model for simulating a case study of NPF in the eastern Mediterranean region. Monoterpenes contributing to NPF can explain a large fraction of the observed NPF events according to our model simulations. However the adjusted parameterization resulting from our sensitivity tests was significantly different from the initial one that had been determined for the boreal environment. 


\section{Introduction}

Most of the atmospheric aerosol particles, and a substantial fraction of particles able to act as cloud condensation nuclei $(\mathrm{CCN})$, have been estimated to originate from new particle formation (NPF) taking place in the atmosphere (Spracklen et al., 2006; Kerminen et al., 2012; Gordon et al., 2017). The exact mechanisms driving atmospheric NPF and subsequent particle growth processes are still not fully understood nor are the roles of different vapors and ions in these processes (Kulmala et al., 2014; Lehtipalo et al., 2016; Tröstl et al., 2016). In order to understand how aerosol particles affect regional and global climate and air quality, it is necessary to quantify the factors that determine the occurrence of NPF and characterize the parameters that describe the strength of NPF, such as the new particle formation and growth rates, in various environments.

While NPF has been reported to take place worldwide (Kulmala et al., 2004a; Wang et al., 2017), observational studies on this subject are scarce in rural subtropical environments. It has been shown that the processes responsible for particle formation and growth differ substantially across the European continent (Dall'Osto et al., 2018).

Several studies have investigated NPF in the eastern Mediterranean and found it to be a frequent phenomenon. Lazaridis et al. (2006) first reported NPF in the area and correlated these events with polluted air masses. Petäjä et al. (2007) presented NPF in the Athens metropolitan area and showed that under the influence of urban pollution, condensing species leading to growth of the new particles are far more hygroscopic than under cleaner conditions. NPF events have also been reported to be frequent in the urban environment of Thessaloniki (Siakavaras et al., 2016). Kalivitis et al. (2008) showed that precursors and nucleation mode particles experience strong scavenging on Crete during summer. Pikridas at al. (2012) suggested that nucleation events occurred only when accumulation mode particles were neutral, being consistent with the hypothesis that a lack of $\mathrm{NH}_{3}$, during periods when particles are acidic, may limit nucleation in sulfate-rich environments such as the eastern Mediterranean. Additionally, based on ion observations, Pikridas et al. (2012) showed that NPF is more frequent in winter. By using the same data set from the eastern Mediterranean, Kalivitis et al. (2012) reported nighttime enhancements in ion concentrations with a plausible association with NPF, being among the very few locations where such observations have been made. Manninen et al. (2010) presented an analysis of a full year of observations of NPF with atmospheric ion spectrometers at various locations across Europe during the EUCAARI project and showed that NPF is less frequent at the eastern Mediterranean site than at other, mostly continental, European sites. On the other hand, Berland et al. (2017) showed that similar patterns are being observed throughout the Mediterranean when comparing observations from the island of Crete to a western Mediterranean site in terms of the frequency of occurrence, seasonality, and particle formation and growth rates. Kalivitis et al. (2015), for the first time, studied the NPF-CCN link using observations of particle number size distributions, $\mathrm{CCN}$ and high-resolution aerosol chemical composition for the eastern Mediterranean atmosphere. From the hygroscopicity of the particles in different size fractions, it was concluded that smaller particles during active NPF periods tend to be less hygroscopic (and richer in organics) than larger ones. Finally, Kalkavouras et al. (2017) reported that NPF may result in higher CCN number concentrations, but the effect on cloud droplet number is limited by the prevailing meteorology.

In this work, we present results from the analysis of 10 years of aerosol particles number size distributions and more than 2 years of atmospheric ion size distributions, representing one of the longest published NPF data set in the Mediterranean atmosphere. The main questions we wanted to address were as follows: (1) How often does NPF take place in the eastern Mediterranean, what are the characteristics of this phenomenon and to what extent has it changed over the period under study? (2) Are there features in NPF observed at the study area that are not common in other locations? (3) How well can numerical models, used in different environmental conditions, represent NPF in this subtropical environment?

\section{Materials and methods}

\subsection{Measurements}

Measurements presented in this work were carried out at the atmospheric observation station of the University of Crete at Finokalia, Crete, Greece ( $35^{\circ} 20^{\prime} \mathrm{N}, 25^{\circ} 40^{\prime} \mathrm{E} ; 250 \mathrm{~m}$ a.s.l.) over 10 years, between June 2008 and June 2018. The Finokalia station (http://finokalia.chemistry.uoc.gr/, last access: 20 February 2019) is a European supersite for aerosol research, part of the ACTRIS (Aerosols, Clouds, and Trace gases Research Infrastructure) Network. The station is located at the top of a hill over the coastline, in the northeast part of the island of Crete (Mihalopoulos et al., 1997). The station is representative of the marine background conditions of the eastern Mediterranean (Lelieveld et al., 2002), with negligible influence from local anthropogenic sources. The nearest major urban center in the area is Heraklion with approximately 200000 inhabitants, located about $50 \mathrm{~km}$ to the west of the station.

In order to monitor the NPF events, a TROPOS-type custom-built scanning mobility particle sizer (SMPS), similar to the IFT-SMPS in Wiedensohler et al. (2012), was used at Finokalia. Particle number size distributions were measured in the diameter range of 9-848 $\mathrm{nm}$ every $5 \mathrm{~min}$. The system was a closed loop, with a 5:1 ratio between the aerosol and sheath flow, and it consisted of a $\mathrm{Kr}$ 85 aerosol neutralizer (TSI 3077), a Hauke medium dif- 
ferential mobility analyzer (DMA) and a TSI-3772 condensation particle counter (CPC). The sampling was done through a $\mathrm{PM}_{10}$ sampling head, and the sample humidity was regulated below the relative humidity of $40 \%$ with the use of Nafion ${ }^{\circledR}$ dryers in both the aerosol and sheath flow. The measured number size distributions were corrected for particle losses by diffusion on the various parts of the SMPS according to the methodology described in Wiedensohler et al. (2012). Three different types of calibration were performed for the SMPS, DMA voltage supply calibration, aerosol and sheath flows calibrations and size calibrations. These measurements have been performed at Finokalia on a continuous basis since 2008. The instrument used at Finokalia was audited on-site with good results in the framework of the EUSAAR (European Supersites for Atmospheric Aerosol Research) project (http://www. wmo-gaw-wcc-aerosol-physics.org/audits.html, last access: 20 February 2019) and has successfully passed laboratory intercomparison workshops twice (2013 and 2016, reports available at http://www.wmo-gaw-wcc-aerosol-physics.org/ instrumental-workshops.html, last access: 20 February 2019) in the framework of the ACTRIS project. The instrument has been operated following the recommendations described in Wiedensohler et al. (2012). Additional information for newly formed particles was obtained with the use of an air ion spectrometer (AIS-AIREL Ltd., Institute of Environmental Physics, University of Tartu, Estonia; Mirme et al., 2007). AIS is a cluster ion air spectrometer used to simultaneously measure electrical mobility distribution of positive and negative air ions (mobilities in the range of 2.4 to $1.3 \times 10^{-3} \mathrm{~cm}^{2} \mathrm{~V}^{-1} \mathrm{~s}^{-1}$ ). The mobility distributions were then transformed to size distributions in the size range 0.8 $42 \mathrm{~nm}$. The number counting threshold was approximately $10 \mathrm{~cm}^{-3}$ and the uncertainties of the AIS measurements were $\sim 10 \%$ for negative and positive ion concentrations and $\sim 0.5 \mathrm{~nm}$ for size (Manninen et al., 2010). The diameter of the AIS inlet tube was $35 \mathrm{~mm}$ and the sample flow rate was $60 \mathrm{~L} \mathrm{~m}^{-1}$. The time step of the measurements was $5 \mathrm{~min}$.

These measurements have been used to identify NPFs for the whole period and provide a historical perspective for the frequency and the characteristics of NPF phenomena in the eastern Mediterranean. Calculations for formation rates of new particles $(J)$, growth rates (GRs) in various size ranges and condensation sink (CS) were made according to Kulmala et al. (2012). Formation rates of particles with diameter $D_{\mathrm{p}}$ (in this study $D_{\mathrm{p}}=9 \mathrm{~nm}$ ) were calculated as

$$
J_{D_{\mathrm{p}}}=\frac{\Delta N_{D_{\mathrm{p}}}}{\Delta t}+\mathrm{CoagS} \cdot N_{D_{\mathrm{p}}}+\frac{\mathrm{GR}}{\Delta D_{\mathrm{p}}} \cdot N_{D_{\mathrm{p}}}+S_{\text {losses }} .
$$

$\Delta N_{D_{\mathrm{p}}}$ is the increase in nucleation mode particles' number concentration $\left(D_{\mathrm{p}}<25 \mathrm{~nm}\right)$, CoagS is the coagulation of $9 \mathrm{~nm}$ particles on larger particles and GR is the growth rate in the size range $9-25 \mathrm{~nm}$. $S_{\text {losses }}$ takes into account additional losses and was ignored in this study. GR was calculated using the mode-fitting method (Dal Maso et al., 2005).
The aerosol size distributions were fitted with lognormal distributions, and the nucleation mode geometric mean diameter was plotted as a function of time. GR was calculated as the slope of the linear fit so that

$$
\mathrm{GR}=\frac{\mathrm{d} D_{\mathrm{p}}}{\mathrm{d} t} .
$$

CS is the condensation sink caused by the preexisting aerosol population and was calculated using the properties of sulfuric acid as condensing vapor.

All important meteorological parameters were monitored every 5 min using an automated meteorological station, including the temperature, wind velocity and direction, relative humidity, solar irradiance, and precipitation. Ozone concentrations were measured with a TEI 49C instrument and nitrogen oxides with a TEI 42CTL, both commercially available, with a time step of $5 \mathrm{~min}$.

\subsection{NPF simulations with the MALTE-Box model}

The simulations of NPF events in the eastern Mediterranean atmosphere were here performed using the MALTE-Box model of the University of Helsinki. This 0-D model able to simulate aerosol dynamics and chemical processes has successfully reproduced observations of aerosol formation and growth in the boreal environment (Boy et al., 2006) as well as in highly polluted areas (Huang et al., 2016). For the present study, chemical reactions relevant to the production of condensing species from the Master Chemical Mechanism (MCM) were incorporated in the MALTE-Box chemical mechanism, as described in Boy et al. (2013). These include the full MCM degradation scheme of the following volatitle organic compounds (described in more detail in Tzitzikalaki et al., 2017): $\mathrm{C}_{1}-\mathrm{C}_{4}$ alkanes, $\mathrm{C}_{2}-\mathrm{C}_{3}$ alkenes, acetylene, isoprene, $\alpha$ - and $\beta$-pinene, aromatics, methanol, dimethyl sulfide, formaldehyde, formic and acetic acids, acetaldehyde, glycoaldehyde, glyoxal, methylglyoxal, acetone, hydroxyacetone, butanone, and marine amines. The Kinetic PreProcessor (KPP) was used to produce the Fortran code for the calculations of the concentrations of each individual compound (Damian et al., 2002), except for those species whose concentrations were manually input from large-scale model simulations.

The major aerosol dynamical processes for clearsky atmosphere were simulated by the size-segregated aerosol model UHMA (University Helsinki Multicomponent Aerosol Model; Korhonen et al., 2004) included in the MALTE-Box model. Measured aerosol number size distributions were used to initialize UHMA daily, which simulates NPF, coagulation, growth and dry deposition of particles. UHMA simulated new cluster formation using the activation nucleation parameterization, so that the nucleation rate has a linear relationship with sulfuric acid concentration, depending on the nucleation coefficient $K_{\text {act }}$. 
Apart from sulfuric acid, about 20 extremely low-volatility organic compounds (ELVOCs) and 7 selected semi-volatile organic compounds (SVOCs) were treated as condensing vapors, following the simplified chemical mechanism presented in Huang et al. (2016). All condensing compounds were treated either as sulfuric acid or organic compounds, and the condensation of organic vapors was determined by the nano-Kohler theory (Kulmala et al., 2004b).

The observations at Finokalia station were used as input to the MALTE-Box model, and when such observations were not available, the results from numerical simulations with the global three-dimensional chemistry transport model (CTM) TM4-ECPL (Daskalakis et al., 2015, 2016; Myriokefalitakis et al., 2010, 2016) for Finokalia were used. Observational data include temperature, relative humidity, total radiation (meteorological input), ozone $\left(\mathrm{O}_{3}\right)$ and nitrogen oxides $\left(\mathrm{NO}_{x}\right)$ concentrations as well as aerosol number size distributions. The aerosol number size distribution measured by the SMPS was used to calculate the condensation sink for $\mathrm{H}_{2} \mathrm{SO}_{4}$ vapors. Due to the lack of detailed measurements of volatile organic compounds (VOCs) at Finokalia, as a first approximation, biogenic and anthropogenic concentrations of all the abovementioned VOCs resolved every $3 \mathrm{~h}$ were taken from the TM4-ECPL model.

The global TM4-ECPL model was run driven for this study by ECMWF (European Centre for Medium - Range Weather Forecasts) Interim re-analysis project (ERA - Interim) meteorology (Dee et al., 2011) of the year 2012 at a horizontal resolution of $3^{\circ}$ in longitude $\times 2^{\circ}$ in latitude with 34 vertical layers up to $0.1 \mathrm{hPa}$. The model used year-specific meteorology and emissions of trace gases and aerosols. For this study, that of the year 2012 was used, except for soil $\mathrm{NO}_{x}$ and oceanic $\mathrm{CO}$ and VOC emissions, which were taken from the POET inventory database for the year 2000 (Granier et al., 2005). TM4-ECPL simulations for this work were performed with a model time step of $30 \mathrm{~min}$, and the simulated VOC concentrations every $3 \mathrm{~h}$ were used as input to the MALTE box model; $\mathrm{SO}_{2}$ surface levels at Finokalia were taken from the Monitoring Atmospheric Composition and Climate (MACC) data assimilation system (Inness et al., 2013).

For the calculations of the photodissociation rate coefficient by the MALTE-Box model, the solar actinic flux (AF) is needed. Unfortunately, AF was not measured at Finokalia in 2012; therefore, AF levels were calculated by the Tropospheric Ultraviolet and visible Radiation Model (TUV; Madronich, 1993) version v.5 for cloud-free conditions. The ability of TUV to calculate the AF at Finokalia was investigated by comparing observations of photodissociation rates of $\mathrm{O}_{3}\left(J \mathrm{O}^{1} \mathrm{D}\right)$ and $\mathrm{NO}_{2}\left(J \mathrm{NO}_{2}\right)$ and model calculations. The measurements of these photodissociation rates were performed by filter radiometers (Meteorologie Consult, Germany). The $J \mathrm{O}^{1} \mathrm{D}$ was measured at wavelengths $<325 \mathrm{~nm}$, while for $\mathrm{JNO}_{2}$ wavelengths $<420 \mathrm{~nm}$ were used.
A series of sensitivity tests of AF to different input parameters was also performed to optimize the calculations. The model uses extraterrestrial solar spectral irradiance (200$1000 \mathrm{~nm}$ by $0.01 \mathrm{~nm}$ steps) and computes its propagation through the atmosphere taking into account multiple scattering and the absorption and scattering due to gases and particles. TUV inputs of interest were surface reflectivity (albedo), $\mathrm{O}_{3}$ column, aerosol optical depth at $500 \mathrm{~nm}$ (AOD), single scattering albedo of aerosol (SSA), $\mathrm{NO}_{2}$ column and air density. Total $\mathrm{O}_{3}$ column values were taken from the Ozone Monitoring Instrument (OMI) on the Aura spacecraft of NASA (Levelt et al., 2006). Aerosol columnar optical properties were obtained from the Aerosol Robotic Network (AERONET). AOD data were measured at the FORTH_Crete station which is located $35 \mathrm{~km}$ west of Finokalia (Fotiadi et al., 2006). Data level 1.5 from Version 2 were used (cloud-screened). Total $\mathrm{NO}_{2}$ column values were taken from the Global Ozone Monitoring Experiment-2 (GOME-2) and OMI instruments. The calculations were carried out at wavelength from 280 to $650 \mathrm{~nm}$ with a resolution of $5 \mathrm{~nm}$. Simulations using surface reflectivity of 0.075 and simulations using $\mathrm{O}_{3}$ column taken from OMI had the best correlation with measurements. However, the TUV model still significantly overestimated $J \mathrm{O}^{1} \mathrm{D}$ and $J \mathrm{NO}_{2}$ data. Thus, a parameterization took place following a simple empirical approach, according to Mogensen et al. (2015), and the ratios between the measured and modeled (from TUV) photolysis rate were calculated and used in the model.

\section{Results and discussion}

\subsection{Particle size distribution and its connection with NPF}

We analyzed all available measurements of number size distributions of atmospheric aerosol particles measured at Finokalia in order to identify and analyze the NPF phenomenon in the eastern Mediterranean. The data coverage for the period 2008-2018 was $82 \%$, providing one of the longest time series of size distributions not only in this region but also in southern Europe and a unique database for aerosol physical properties.

First, we calculated the total particle number concentration (median concentration was $2202 \mathrm{~cm}^{-3}$, standard deviation (SD) $528 \mathrm{~cm}^{-3}$ ) and corresponding number concentration in the nucleation mode $\left(D_{\mathrm{p}}<25 \mathrm{~nm}\right.$, median $80 \mathrm{~cm}^{-3}$, SD $\left.528 \mathrm{~cm}^{-3}\right)$, Aitken mode $\left(25 \mathrm{~nm}<D_{\mathrm{p}}<100 \mathrm{~nm}\right.$, median $\left.1028 \mathrm{~cm}^{-3}, \mathrm{SD} 894 \mathrm{~cm}^{-3}\right)$ and accumulation mode $\left(D_{\mathrm{p}}>\right.$ $100 \mathrm{~nm}$, median $898 \mathrm{~cm}^{-3}$, SD $605 \mathrm{~cm}^{-3}$ ). We found that Aitken mode accounted for $50 \%$ and accumulation mode for $42 \%$ of the total particle number concentration, while the nucleation mode accounted only for $8 \%$. The standard deviation of the nucleation particle number concentration was $528 \mathrm{~cm}^{-3}$, indicating that the abundance of these smallest 

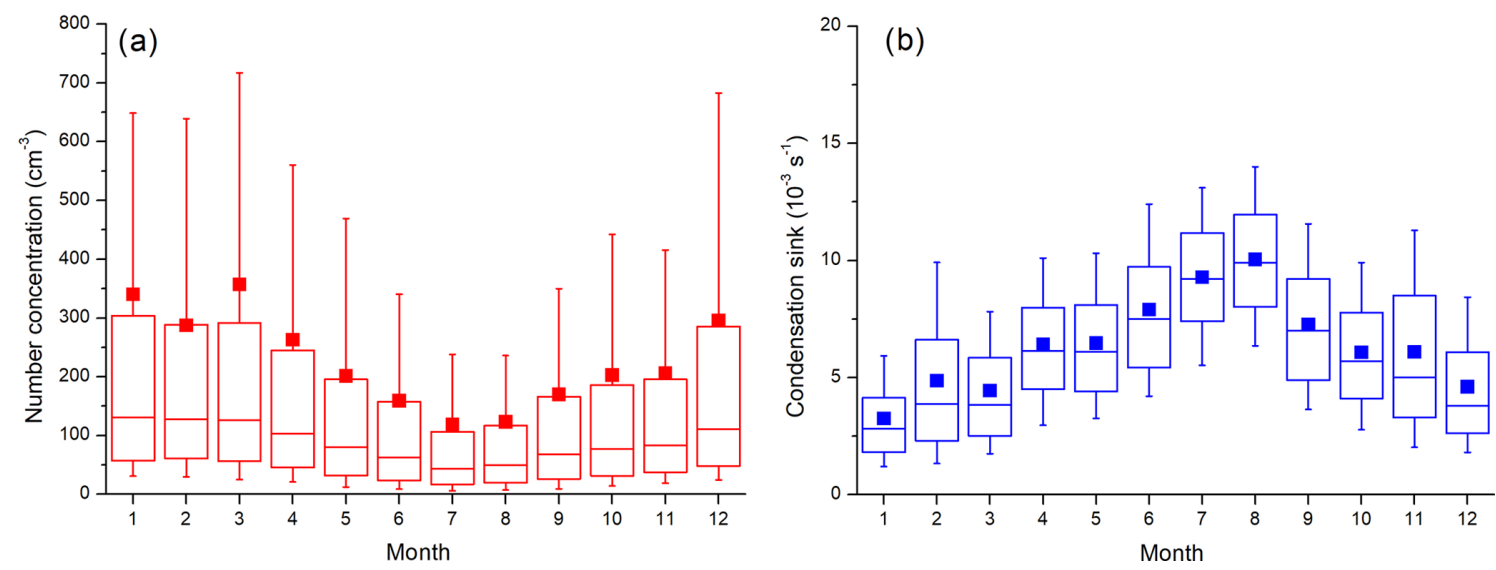

Figure 1. Monthly average variation in (a) nucleation mode particle number concentration and (b) sulfuric acid condensational sink (CS) at Finokalia station over the period June 2008-June 2018. Whiskers represent 10th and 90th percentiles, box edges are 75th and 25th percentiles, the line in the box is the median, and the solid square is the mean.

particles is of an episodic nature. The highest monthly average concentrations of nucleation mode particles were observed during winter and early spring and the lowest ones during summer (Fig. 1a). Calculating the median diurnal variability of the nucleation mode, we can see that there is a clear pattern for all seasons of the year (Fig. 2a) with a sudden burst in the number concentration around noon that is most pronounced in winter and least in summer. Such an observation suggests that the nucleation particle number concentration is controlled by NPF episodes rather than other sources such as combustion processes. As can be seen in Fig. 2b, where a typical "banana-shaped" pattern of an NPF event at Finokalia is presented, the sudden burst at noon is typical for a NPF event. In summer, nucleation mode particles have the highest concentrations during the night, yet another concentration relative maximum at noon can be attributed to NPF (Fig. 2a). The shift in the average time of the daytime burst of nucleation mode particles can be attributed to the annual variation in the daylight length. Similar observations to ours have been reported in Cusack et al. (2013) for the western Mediterranean where the diurnal variation in nucleation mode particles presents a clear maximum at noon under both polluted and clean conditions.

It is worth noticing that during nighttime the median nucleation mode particle number concentrations were similar in all the seasons. This suggests that there is some new particle production mechanism at night, especially in summer and autumn, that operates separately from daytime NPF. Frequently during the nighttime, we observed a pronounced appearance of new nucleation mode particles over several hours as illustrated by Fig. 3. While nocturnal NPF has been reported in the literature (see Salimi et al., 2017, and references therein), this phenomenon seems to be rare and it remains unclear what the exact mechanisms leading to it are. Given that we observed no or little growth during nighttime NPF, we may assume that the sources leading to the formation of new par-
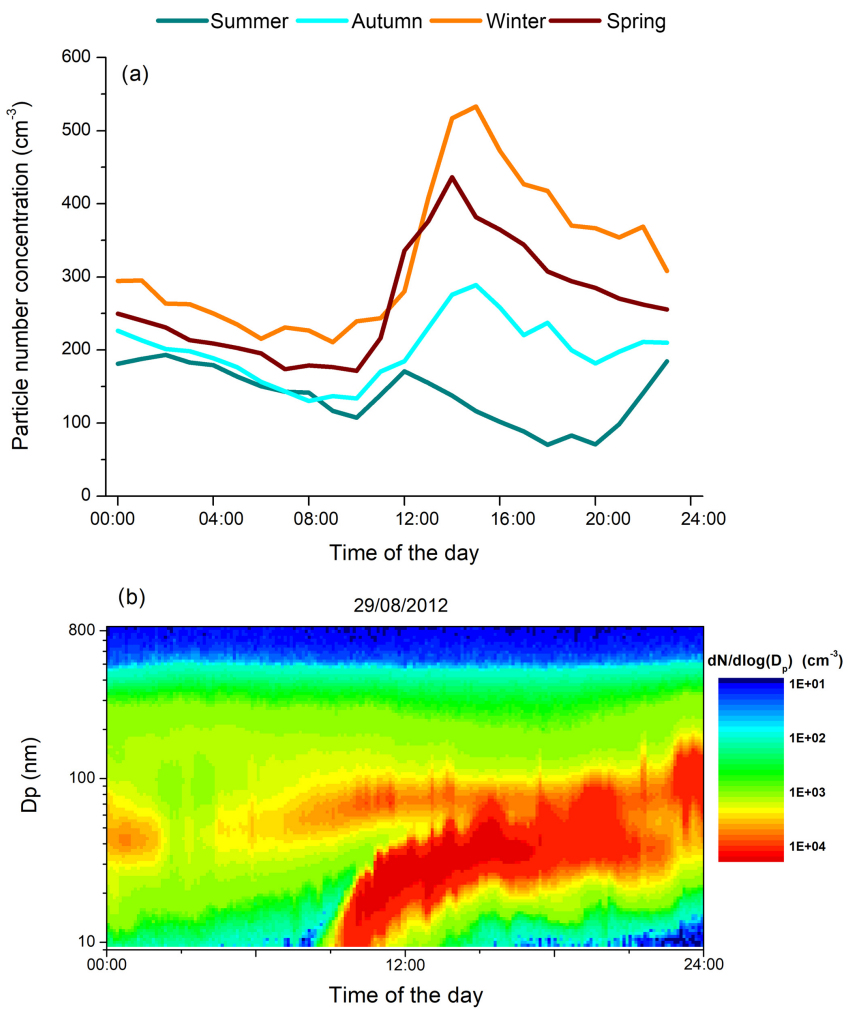

Figure 2. (a) Average diurnal variation in nucleation mode particle number concentration (hourly values) at Finokalia over the period June 2008-June 2018. (b) New particle formation event captured at Finokalia on 29 August 2012 (time in UTC+2).

ticles are local rather than regional and that the lack of photochemistry during night limits the abundance of condensable vapors driving particle growth. Observations of very localized NPF have been reported in Mace Head, Ireland, where intense NPF frequently takes place under low tide conditions 


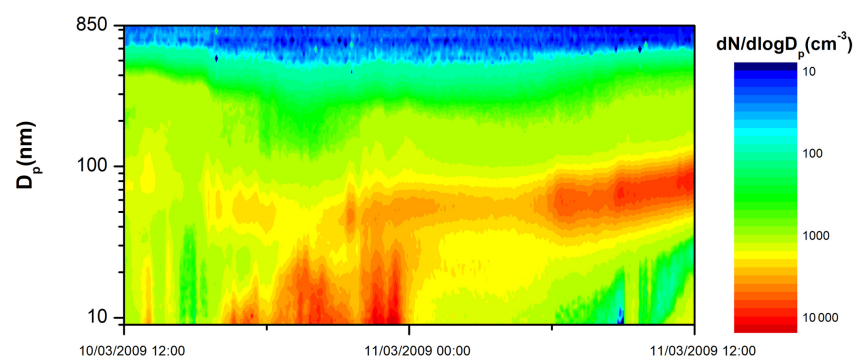

Figure 3. Example of appearance of nucleation mode particles during several hours as observed during the night of 10 to 11 March 2009 (time in UTC+2).

when algae are exposed to the atmosphere (O'Dowd et al., 2002). Henceforth, we will exclude the nighttime NPF events from our further analysis. We refer the interested reader to Kalivitis et al. (2012) for a more detailed description of this phenomenon.

Overall, we observed atmospheric NPF to take place during both day and night at Finokalia but no sign of any other source of nucleation mode particles in measured air masses. We therefore hypothesize that atmospheric NPF is the dominant source of nucleation mode particles in this Mediterranean environment.

\subsection{Characteristics of NPF in the eastern Mediterranean}

We analyzed the data set of aerosol size distributions following the approach of Dal Maso et al. (2005) in order to mark the available days as (1) NPF event days when a clear new nucleation mode and subsequent growth of newly formed particles to larger diameters can be observed, (2) non-event days, and (3) undefined days when either new particles appear into the Aitken mode or nucleation mode particles do not show a clear growth. The available days were manually inspected and classified.

We used the Statistica software package for Windows to carry out factor analyses, including meteorological parameters, ozone concentrations (as an important oxidant in the atmosphere) and $\mathrm{PM}_{10}$ mass concentration (as an index of particulate pollutant levels), in order to examine whether any of these factors were associated with the formation of new particles, represented by the nucleation mode number concentration. Furthermore, we divided our data into night and day time periods in order to separate daytime NPF from that taking place during nighttime. The only parameter that had some effect on the nucleation mode particle number concentration was the wind velocity: when strong winds were prevailing at Finokalia, it was more unlikely to observe nucleation particles. On the other hand, the lack of correlation with any other parameter may indicate that the NPF is not sensitive to local meteorological conditions, preexisting particulate matter and ozone levels in this environment. Air mass back trajecto-
Table 1. Total available measurement days and percentage of NPF events observed at Finokalia during the period June 2008-June 2018.

\begin{tabular}{lrr}
\hline $\begin{array}{l}\text { Day } \\
\text { classification }\end{array}$ & $\begin{array}{r}\text { Number of } \\
\text { events }\end{array}$ & $\%$ \\
\hline Total events & 837 & 27.4 \\
\hline Class I & 232 & 7.6 \\
Class II & 605 & 19.8 \\
\hline Undefined & 687 & 22.5 \\
Non-event & 1533 & 50.1 \\
\hline Total days & 3057 & 100.00 \\
\hline
\end{tabular}

ries calculated using the HYSPLIT model (Stein et al., 2015) showed little difference during NPF events from air masses typical for the prevailing situation at Finokalia: air masses arriving at Finokalia from the northeast were the most frequent during NPF events (30\% against $24 \%$ of all days), followed by northern directions ( $20 \%$ against $21 \%$ ) and northwestern air masses that were more frequent than the average $(19 \%$ against $17 \%$ ).

Next, we focused on determining the main characteristics of daytime NPF at Finokalia. Overall, 837 NPF events were identified. This is one of the longest time series of the NPF phenomenon recorded in the Mediterranean atmosphere, providing a representative climatology of NPF events in this region. NPF took place on $27 \%$ of the 3057 available measurement days whereas no event occurred on $50 \%$ of those days. It is worth noting that $23 \%$ of the days were characterized as undefined, which means that while no clear NPF event could be observed, there was some evidence of secondary particle formation although not in the immediate vicinity of the station (Table 1). We found that NPF is most frequent in April and May, probably due to the biogenic activity and the onset of intense photochemistry, and least frequent in August (Fig. 4) probably due to high wind speeds occurring in these months (not shown) and additionally the high condensational sink (Fig. 1b). The rain season in southeastern Europe in early autumn leads to a gradual CS decrease, and as a result a local maximum in NPF frequency is observed in October. NPF at Finokalia takes place throughout the year.

As a next step, we classified the NPF events as Class I or Class II events depending on whether the particle formation rate at $9 \mathrm{~nm}\left(J_{9}\right)$ and growth rates from 9 to $25 \mathrm{~nm}$ diameter (GR $9-25)$ could be calculated with good confidence or not. Overall, Class I events corresponded to $8 \%$ of the available measuring days and $28 \%$ of the event days, and they were observed throughout the year, providing enough data for a statistical analysis of particle formation and growth rates during NPF events (Fig. 5).

The average value of $J_{9}$ during the Class I NPF events in Finokalia was $0.9 \mathrm{~cm}^{-3} \mathrm{~s}^{-1}$ (median $0.5 \mathrm{~cm}^{-3} \mathrm{~s}^{-1}$, SD 

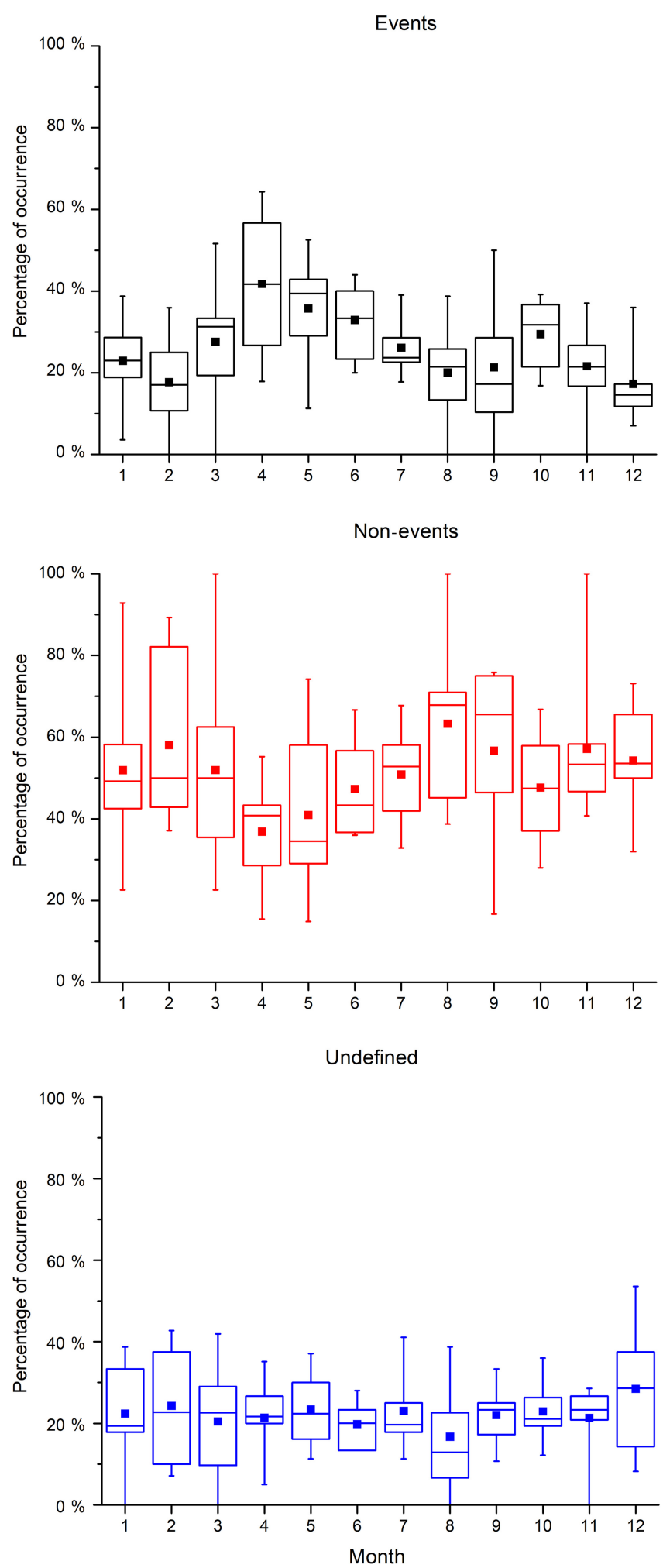

Figure 4. Seasonal variation in NPF percentage of occurrence of event, non-event and undefined days relatively to available measurement days at Finokalia for the period June 2008-June 2018. Whiskers represent 10th and 90th percentiles, box edges are 75th and 25th percentiles, the horizontal line in the box is the median, and the square is the mean.

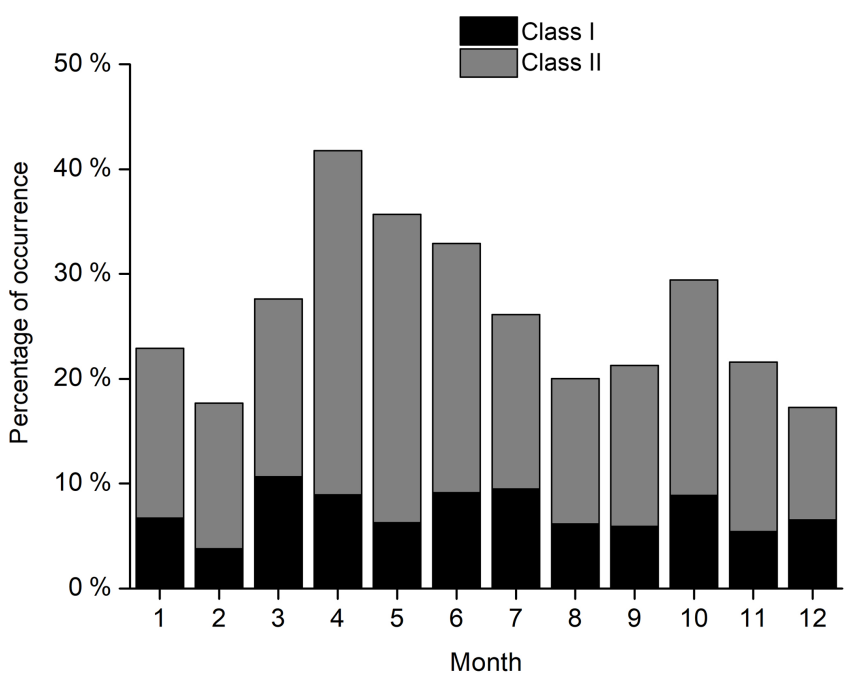

Figure 5. Seasonal variation in percentage of occurrence of NPF Class I and II events relatively to available measurement days at Finokalia in the eastern Mediterranean for the period June 2008June 2018.

$\left.1.2 \mathrm{~cm}^{-3} \mathrm{~s}^{-1}\right)$. This is well within the range of values reported for $J_{10}$ at other locations (Kulmala et al., 2004a), although higher than $J_{16}$ reported by Berland et al. (2017) at the Finokalia site in $2013\left(0.26 \mathrm{~cm}^{-3} \mathrm{~s}^{-1}\right)$, but substantially lower than the values found by Kopanakis et al. (2013) in western Crete $\left(13.1 \pm 9.9 \mathrm{~cm}^{-3} \mathrm{~s}^{-1}\right)$. The monthly variation in $J_{9}$ (Fig. 6a) shows that the highest average formation rates were observed in December and January, probably as a result of the low CS values observed in winter, although it is difficult to say which factors determine the monthly variability of $J_{9}$ at Finokalia. Seasonal averages of $J_{9}, G_{9-25}$ and CS are summarized in Table 2. Moreover, we found that $J_{9}$ and $N_{9-25}$ have a clear linear relation (Fig. 7), which supports our earlier hypothesis that at Finokalia the main source of nucleation mode particles is their secondary formation in the atmosphere.

We calculated the average growth rate of the newly formed particles to be $5.4 \mathrm{~nm} \mathrm{~h}^{-1}$ (median $4.5 \mathrm{~nm} \mathrm{~h}^{-1}$, SD $3.9 \mathrm{~nm} \mathrm{~h}^{-1}$ ). We found that $\mathrm{GR}_{9-25}$ is highest in summer until September and lowest in winter and early spring, probably in line with the seasonal cycle of photochemical activity and biogenic emission patterns, producing condensable species that are driving the growth process (Fig. 6b). Additionally, transported pollution in summer at Finokalia may contribute except for that of CS to GR, since transported anthropogenic $\mathrm{SO}_{2}$ is a precursor for condensable sulfuric acid.

The survival probability of newly formed particles is closely related to the ratio of CS to GR, at least for cluster sizes (Kerminen and Kulmala, 2002; Kulmala et al., 2017), and at Finokalia they present the same annual cycle. The survival probability for nucleation mode particles for Class I events was calculated based on the formula in Kulmala et 

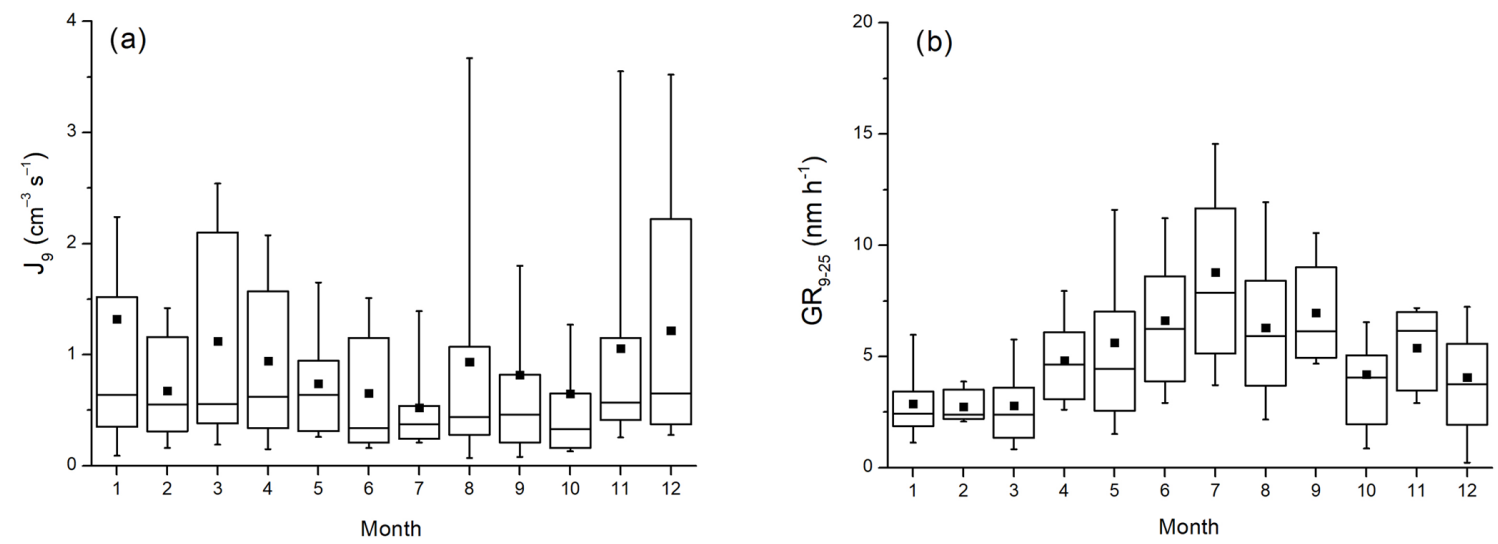

Figure 6. Seasonal variation in (a) formation rate of $9 \mathrm{~nm}$ particles $\left(J_{9}\right)$ and (b) growth rate in the size range $9-25 \mathrm{~nm}\left(\mathrm{GR}_{9-25}\right)$ as calculated during Class I NPF events at Finokalia for the period June 2008-June 2018. Whiskers represent 10th and 90th percentiles, box edges are 75 th and 25 th percentiles, the horizontal line in the box is the median, and the solid square is the mean.

Table 2. Formation rates for $9 \mathrm{~nm}$ particles $\left(J_{9}\right)$, growth rates in the size range $9-25 \mathrm{~nm}\left(\mathrm{GR}_{9-25}\right)$ for NPF events observed at Finokalia and condensational sink for sulfuric acid (CS) on a seasonal basis during the period June 2008-June 2018 (mean, median and standard deviation).

\begin{tabular}{lrrr|rrr|rr|r}
\hline & \multicolumn{3}{c|}{$J_{9}\left(\mathrm{~cm}^{-3} \mathrm{~s}^{-1}\right)$} & \multicolumn{2}{c|}{$\mathrm{GR}_{9-25}\left(\mathrm{~nm} \mathrm{~h}^{-1}\right)$} & \multicolumn{2}{c}{$\mathrm{CS} \times 10^{-3}\left(\mathrm{~s}^{-1}\right)$} \\
\cline { 2 - 10 } & Mean & Median & SD & Mean & Median & SD & Mean & Median & SD \\
\hline Winter & 0.9 & 0.6 & 1.4 & 3.3 & 2.6 & 2.4 & 4.3 & 3.5 & 2.9 \\
Spring & 1.0 & 0.6 & 1.0 & 4.2 & 3.3 & 3.1 & 5.8 & 5.5 & 3.0 \\
Summer & 0.7 & 0.5 & 0.9 & 7.3 & 6.8 & 3.9 & 9.1 & 9.0 & 3.1 \\
Autumn & 0.8 & 0.4 & 1.0 & 5.3 & 4.7 & 2.9 & 6.5 & 6.0 & 3.4 \\
\hline
\end{tabular}

al. (2017). It was found that on a seasonal basis the median survival probability is higher in summer and winter but varies between the seasons only within $5 \%$. The concentrations of nucleation mode particles are lower during summer and the average duration of the NPF in summer seems to be shorter as shown in Figs. 1 and 2a, respectively. These observations may be explained by the higher CS and GR during summer. The CS (and hence CoagS) may directly affect the maximum concentrations observed. The slightly higher survival probability in summer perhaps explains that given high CS values, new particles need to grow fast in order to survive. On the other hand, one would expect NPF to be most frequent in winter when the highest concentrations of nucleation particles are observed and CS is the lowest, but this was not the case. A possible explanation for the high nucleation mode particle number concentrations in winter could be that the survival probability is higher than in spring or autumn.

\subsection{NPF trends during the 2008-2018 period}

During the period under study no statistically significant trends in NPF events were observed at Finokalia for the 120 available months. It should be noted though, that since 2010 a decreasing trend is observed, which is statistically significant with a $p$ value of 0.005 . During the measurement period under study, no trend in $J_{9}$ was observed (Fig. 8c).
Although no statistically significant trend was observed for GR $_{9-25}$ as well (Fig. 8d), we observed a decreasing trend during the period $2008-2015$ of about $0.3 \mathrm{~nm} \mathrm{~h}^{-1} \mathrm{yr}^{-1}$. This trend can be considered statistically significant ( $p$ value of 0.03). In order to explain this trend, we need to emphasize the regional characteristics of the observations at Finokalia, as this site is greatly affected by long-range transported pollutants of marine, desert dust and polluted continental origin (Lelieveld et al., 2002). Non-sea salt sulfate (nss-SO ${ }_{4}^{2-}$ ) can be considered as an indicator of regional pollution from anthropogenic activities ( $\mathrm{SO}_{2}$ emissions), and since the beginning of the economic crisis in Europe, especially in Greece, we observed a clear decline in its concentration since 2008 (Paraskevopoulou et al., 2015), which, however, stopped after 2015. We can therefore also assume a regional decrease in $\mathrm{SO}_{2}$ emissions, since the main source of $\mathrm{SO}_{2}$ at Finokalia is attributed to transported pollution (Sciare et al., 2003). This could result in a decrease in the availability of sulfuric acid, a major condensable species responsible for particle growth (Bzdek et al., 2012).

Hamed et al. (2010) studied the effect of the reduction in anthropogenic $\mathrm{SO}_{2}$ emissions in Germany between the years 1996-1997 and 2003-2006 as a result of the socioeconomic changes in East Germany after reunification. They observed a notable decrease in the NPF event frequency but an increase 


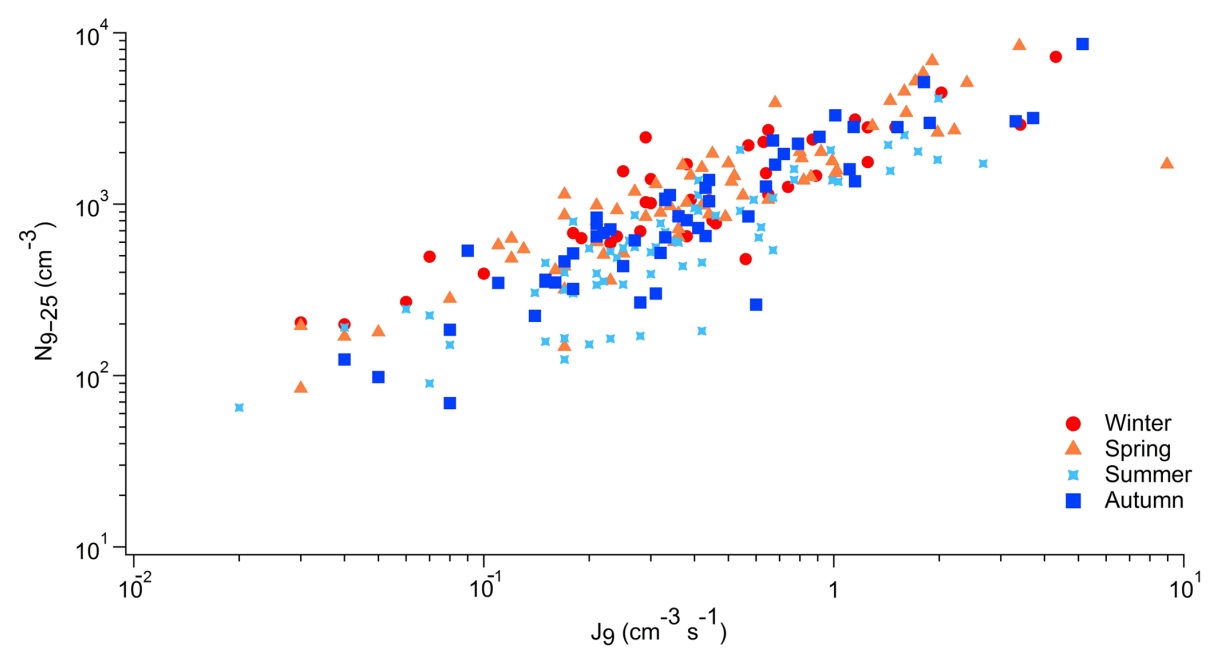

Figure 7. Scatterplot of the number concentration of nucleation mode particles $\left(N_{9-25}\right)$ (hourly maximum value during the event) versus formation rates of $9 \mathrm{~nm}$ particles ( $\left.J_{9}\right)$ at Finokalia, for events when $J_{9}$ could be calculated with a good level of confidence (Class I events).
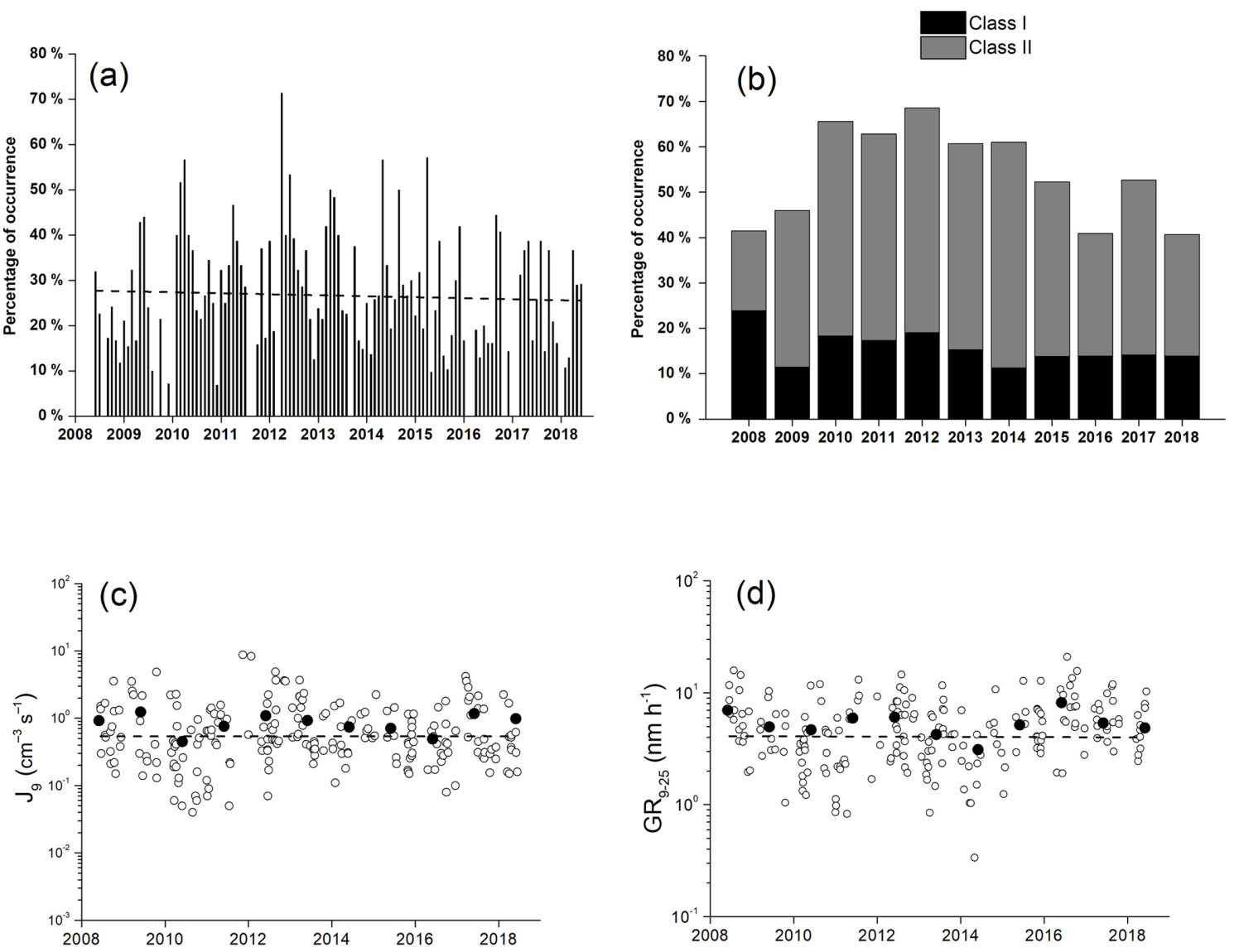

Figure 8. (a) Time series of monthly NPF percentage of occurrence at Finokalia for the years 2008-2018. (b) Annual NPF percentage of occurrence at Finokalia for the period June 2008-June 2018 for Class I and II events. Interannual variation in (c) formation rates of $9 \mathrm{~nm}$ particles $\left(J_{9}\right)$ and $(\mathbf{d})$ growth rate in the size range 9-25 nm (GR9-25) during Class I NPF events at Finokalia for the period June 2008-June 2015 (the solid circles represent annual averages and the dashed lines the linear regression). 
in the growth rate of nucleated particles. A decrease in the $\mathrm{NPF}$ frequency due to the reduction in anthropogenic $\mathrm{SO}_{2}$ emissions in eastern Lapland was also reported by Kyrö et al. (2014), and this decrease was most pronounced for the Class I NPF events. Nieminen et al. (2014) analyzed the longest data set reported in literature from Finland and found that, despite major decreases in ambient $\mathrm{SO}_{2}$ concentrations observed all over Europe as a result of overall air quality improvements, there was a slight upward trend in the particle formation and growth rates. This feature was attributed partly to increased biogenic emissions over the same period.

In our case the reasons for the variations in the NPF frequency, $J_{9}$ and GR ${ }_{9-25}$ remain unclear, even though factors like meteorological conditions and organic vapor abundance have probably played some role in this respect.

\subsection{Atmospheric ion observations related to new particle formation}

At the Finokalia station, atmospheric ion observations relevant to new particle formation were performed during two separate periods: 2008-2009 during the EUCAARI project (Manninen et al., 2010) and 2012-2014 during the FRONT (Formation and growth of atmospheric nanoparticles) project. Here we will focus only on FRONT data, since the EUCAARI data set is discussed in detail in Manninen et al. (2010) and Pikridas et al. (2012). A typical nucleation event is presented in Fig. 9 as recorded by both the AIS and SMPS. AIS observations may provide information about the initial stages of new particle formation as particles can be observed emerging in the intermediate ion diameter range 1.6$7.4 \mathrm{~nm}$. Intermediate ions appear only under certain circumstances, such as during precipitation, at high wind speeds and when NPF is taking place (Hõrrak et al., 1998; Tammet et al., 2014; Leino et al., 2016; Chen et al., 2017). In the following we will focus on NPF and use only the observations from the negative polarity due to the better representation of NPF events in those data compared with corresponding positive ions in our data set (Kalivitis et al., 2012).

We classified all of the available AIS measurement days into event, non-event and undefined days, once again according to methods introduced by Dal Maso et al. (2005), and subsequently compared the findings from AIS data to those from the SMPS. In Fig. 9 an NPF event is presented observed with both the AIS and the SMPS at Finokalia. Surprisingly, the two data sets for the same time period gave quite different results in terms of the NPF event frequency: in the AIS data the NPF event frequency peaked earlier during the year than in the SMPS data (Fig. 10). This feature was evident in both periods of AIS measurements and has been also reported at a rural site in Hungary (Yli-Juuti et al., 2009), probably because AIS detects only naturally charged particles while SMPS detects all particles. Additionally, it is possible that AIS data are more representative of local NPF events with limited particle growth, and such events may not be seen in the SMPS data. On the other hand, the SMPS measures neutral particles but has a much higher detection limit $(9 \mathrm{~nm})$, so its data may be more representative of regional NPF that takes place over distances of hundreds of kilometers (Kalkavouras et al., 2017).

We calculated the growth rates at three different size ranges for the FRONT project similarly to Manninen et al. (2010) and Pikridas et al. (2012) for the EUCAARI project data. The particle growth rates in the size ranges $1.5-3,3-7$ and $7-20 \mathrm{~nm}$ were $1.6 \pm 1.8,5.4 \pm 4.9$ and $9.1 \pm$ $9.5 \mathrm{~nm} \mathrm{~h}^{-1}$, respectively. These values are lower than those in Pikridas et al. (2012) but comparable to those observed during the EUCAARI project for the first two size ranges and higher than those observed during the EUCAARI project for the last size range (Manninen et al., 2010). Overall, we observed much faster growth of newly formed charged particles in the eastern Mediterranean atmosphere after their first growth steps beyond $3 \mathrm{~nm}$ in diameter, reflecting probably the strong Kelvin effect at small particle sizes preventing condensation and hence growth, and the abundance of precursors leading to nucleation and condensing species contributing to each growth stage.

\subsection{Simulations of NPF using the zero-dimensional model MALTE-Box}

In order to evaluate our understanding of the observed NPF events in the eastern Mediterranean we chose to simulate two distinct cases of 1 week's duration each, during which NPF events were observed (event week) or not (non-event week). The selection was done from the summer of the year 2012 , when $J \mathrm{O}^{1} \mathrm{D}$ and $J \mathrm{NO}_{2}$ photodissociation measurements were also available at Finokalia. Two weeks in August and September 2012 were chosen: 28 August-3 September as an event week and 9-15 August as a non-event week. The "event week" was described in detail by Kalivitis et al. (2015). Applying the MALTE-Box model, the aerosol size distribution and its evolution over the week was simulated for these two cases.

During the event week the simulated formation of new particles successfully coincided with the observations. The NPF events simulated using the nucleation rates as parameterized for the boreal environment overestimated the observations, while the simulated growth of newly formed particles was greatly underestimated as shown in Tzitzikalaki et al. (2017). The most likely reason for this is the very low concentration of monoterpenes, calculated by the TM4-ECPL global model for the Finokalia model grid box, on which the ELVOC and SVOC chemistry was built. Indeed, the TM4-ECPL model results for Finokalia were too low compared to monoterpene observations in 2014 (not shown). Therefore, we performed a number of sensitivity tests to improve the simulations by adjusting the nucleation coefficient and the monoterpene concentrations until we simulated efficiently the nucleation and growth rates observed during the second day of the event 


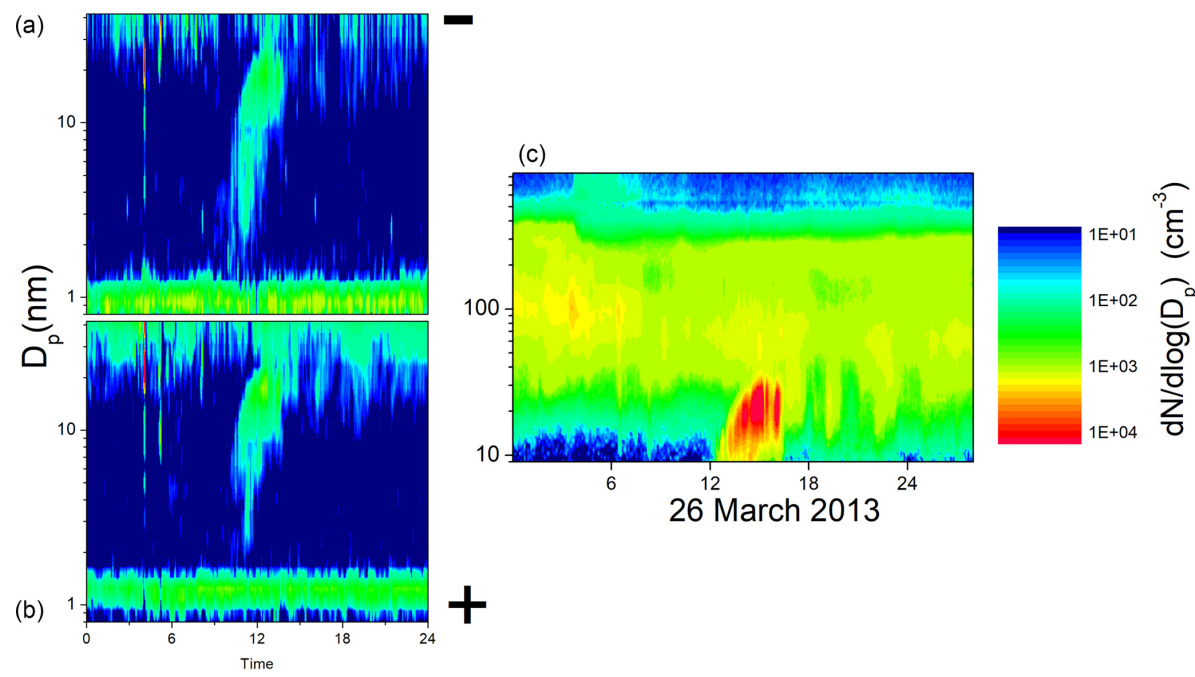

Figure 9. Nucleation event observed at Finokalia on 26 March 2013 as captured by AIS (left panels for negative (a) and positive (b) polarity) and SMPS (c) (time in UTC+2).

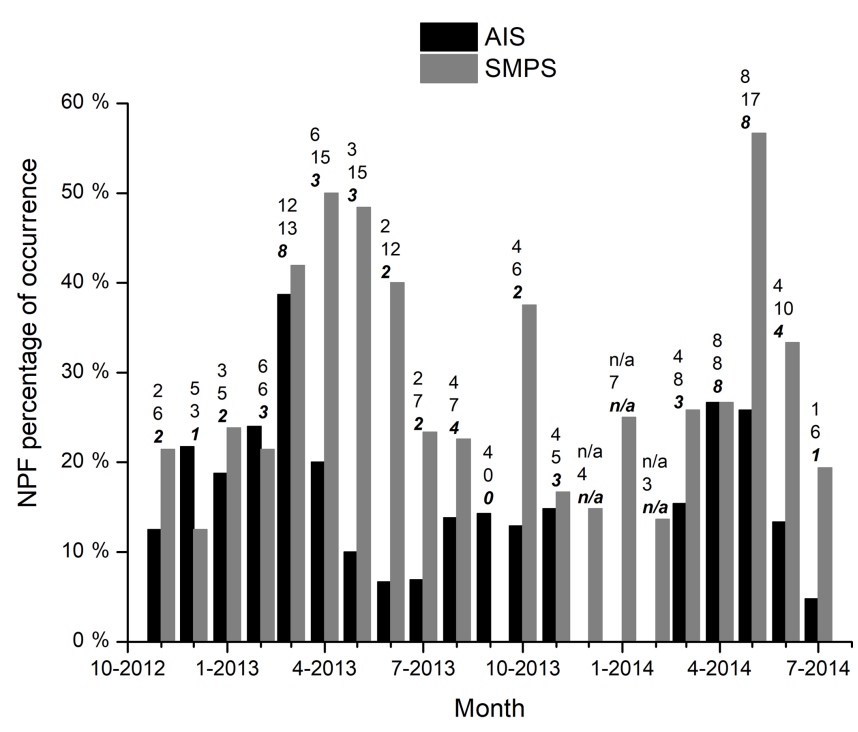

Figure 10. Monthly variability of NPF events' percentage of occurrence relatively to available measurement days at Finokalia as determined by analysis of AIS data during the FRONT experiment (November 2012-July 2014). For a direct comparison, the monthly variability of NPF events as obtained from the SMPS measurements for the same period is included. Above the columns, the number of NPF events observed for AIS (top), SMPS (middle) and the number of common events for both instruments (bottom, italic, bold) for each month are presented. week when the most pronounced NPF event was observed. The best agreement between model results and observations was reached by decreasing the nucleation coefficient from $10^{-11} \mathrm{~s}^{-1}$ (the value commonly used for the boreal environment) to $5 \times 10^{-16} \mathrm{~s}^{-1}$ and increasing the $\alpha$ - and $\beta$-pinene concentrations by a factor of 10 . With these modifications the model results improved and the aerosol number size distributions were better simulated, as were total number and volume concentration of aerosol particles (Fig. 11a and b, respectively). This was the first time that we were able to simulate NPF in the eastern Mediterranean environment. The almost 5 orders of magnitude lower nucleation coefficient used here for the subtropical setup could be related to the contribution of still unknown compounds in the cluster-formation process. Huang et al. (2016) applied different kinetic nucleation coefficients at Nanjing, China, with the lowest value for a "China-clean" day of $6.0 \times 10^{-13} \mathrm{~s}^{-1}$. The higher monoterpene concentrations used are comparable to the findings at Finokalia but also at another location in the eastern Mediterranean (Debevec et al., 2018).

Using the non-event week as our control case, we performed simulations of number size distributions at Finokalia station using the subtropical setup and compared it to our measurements. For the "non-event week", weak NPF were predicted by the model during the last 2 days that were not found in the measurements (Tzitzikalaki et al., 2017) but appear to be associated with the rapid drop in CS during day 5 of the simulations. Nevertheless, even if no NPF took place during the last 2 days, it was apparent in our measurements that some nucleation particles appeared $\left(\sim 200 \mathrm{~cm}^{-3}\right)$, and thus the general tendency was captured by the model. Both total number and volume concentrations were adequately simulated by the model (Fig. 12a, b). These results show the potential of the MALTE-Box model to simulate the NPF 

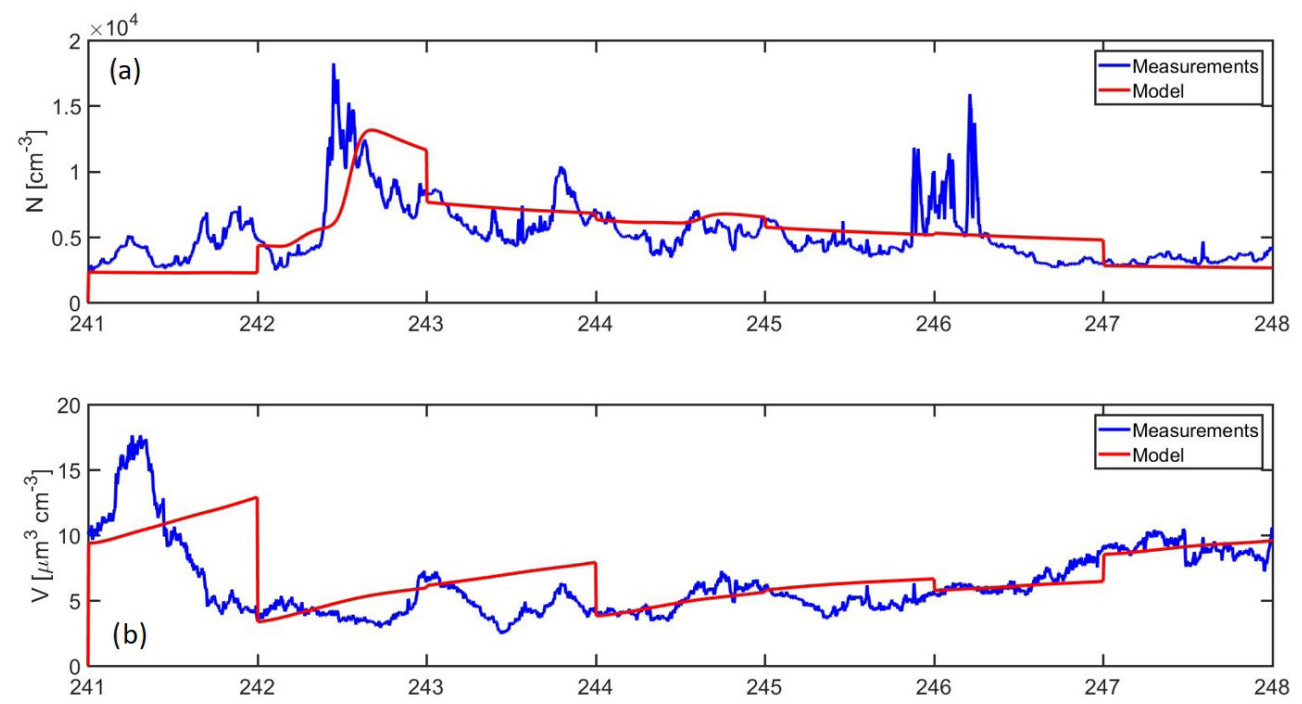

Figure 11. Simulations with the MALTE box with the adjusted parameters for the subtropical environment for the "event week" that NPF events were observed at Finokalia. Measured and modeled (a) total number concentration and (b) total volume concentration for the same period. The $x$ axis in both figures gives the Julian day of 2012 .
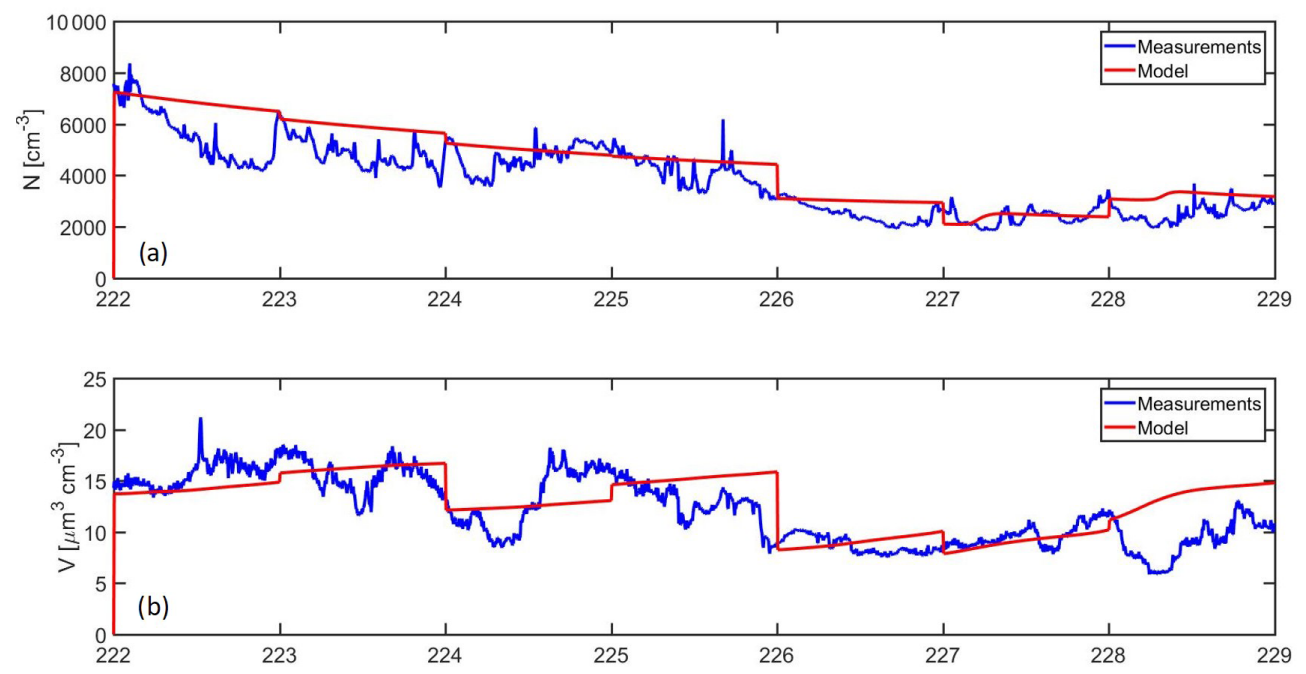

Figure 12. Simulations with the MALTE box with the adjusted parameters for the subtropical environment for the "non-event" week that no NPF was observed at Finokalia. Measured and modeled (a) total number concentration and (b) total volume concentration for the same period. The $x$ axis in both figures gives the Julian day of 2012 .

in the eastern Mediterranean and the importance of input data. Therefore, when more appropriate input data for Maltebox become available (concurrent detailed measurements of gases and aerosol distributions) at Finokalia, new simulations and VOC measurements will provide further insight into the nucleation mechanisms, the growth process and the factors controlling NPF in the eastern Mediterranean atmosphere.

\section{Conclusions}

NPF in the atmosphere is a recurrent phenomenon in the eastern Mediterranean. In this study, we presented the longest time series of NPF records in the region. We analyzed 3057 days of aerosol number size distribution data from June 2008 to June 2018 and found that NPF took place on $27 \%$ of the available days, more frequently in spring and less frequently in late summer. The production of nucleation mode particles was common during nighttime as well. Nucleation mode particle number concentrations were low outside peri- 
ods of active NPF and subsequent particle growth, indicating an absence of local sources. The classification of NPF events based on atmospheric ion measurements differed from the corresponding classification based on mobility spectrometer measurements: the maximum frequency of NPF events was observed earlier in spring from AIS data than from SMPS data, possibly indicating a different representation of local and regional NPF events between these two data sets since SMPS measures new particles after they have grown to diameters larger than $9 \mathrm{~nm}$ and hence records only regional events lasting for several hours.

We used the MALTE-Box model to simulate NPF observations in the eastern Mediterranean region. Using a "subtropical" environment parameterization, we were able to simulate with good agreement the selected time period. The parameterization used was significantly different than the one used for the boreal environment: nucleation rates were much lower, yet monoterpenes seemed to play a key role in the mechanisms governing NPF phenomena.

From the results presented in this work it is evident that the Finokalia site is a unique location in the eastern Mediterranean for studying the processes leading to NPF in the marine environment. As a next step, a more detailed look at the precursors driving these processes is necessary, with special emphasis on VOCs and the expansion of the available measurements at the site in order to eliminate the uncertainties introduced in our simulations by the use of model outputs instead of observations.

Data availability. The data are available from the corresponding authors upon request. The authors acknowledge the free use of $\mathrm{O}_{3}$ data from the OMI sensor accessed via the NASA Aura Validation Data Center at http://avdc.gsfc.nasa.gov (last access: 20 February 2019). Total $\mathrm{NO}_{2}$ column data are the property of the University of Bremen (Andreas Hilboll, personal communication, 2014). The authors gratefully acknowledge the NOAA Air Resources Laboratory (ARL) for the provision of the HYSPLIT transport and dispersion model and the READY website (http://www.ready.noaa.gov, last access: 20 February 2019) used in this publication.

Author contributions. NK, GK, IS, AB, PK and HEM participated in the field measurements and analyzed the data, ET, ND, SM, PR and MB participated in the modeling study, TP, VMK, MKu, MKa and NM contributed to the manuscript preparation.

Competing interests. The authors declare that they have no conflict of interest.

Special issue statement. This article is part of the special issue "CHemistry and AeRosols Mediterranean EXperiments (ChArMEx) (ACP/AMT inter-journal SI)". It is not associated with a conference.
Acknowledgements. The research project was implemented within the framework of the action "Supporting Postdoctoral Researchers" of the operational program "Education and Lifelong Learning" (action's beneficiary: General Secretariat for Research and Technology) and was cofinanced by the European Social Fund (ESF) and the Greek State. This research is supported by the Academy of Finland Center of Excellence program (project number 1118615). We acknowledge funding from the EU FP7-ENV-2013 program "Impact of Biogenic vs. Anthropogenic emissions on Clouds and Climate: towards a Holistic UnderStanding" (BACCHUS), project no. 603445, and the Horizon 2020 research and innovation programme ACTRIS-2 Integrating Activities (grant agreement no. 654109). This study contributes to ChArMEx work package 1 on aerosol sources. We acknowledge support of this work by the project "PANhellenic infrastructure for Atmospheric Composition and climatE change" (MIS 5021516), which is implemented under the action "Reinforcement of the Research and Innovation Infrastructure", funded by the operational programme "Competitiveness, Entrepreneurship and Innovation" (NSRF 2014-2020) and cofinanced by Greece and the European Union (European Regional Development Fund).

Edited by: François Dulac

Reviewed by: two anonymous referees

\section{References}

Berland, K., Rose, C., Pey, J., Culot, A., Freney, E., Kalivitis, N., Kouvarakis, G., Cerro, J. C., Mallet, M., Sartelet, K., Beckmann, M., Bourriane, T., Roberts, G., Marchand, N., Mihalopoulos, N., and Sellegri, K.: Spatial extent of new particle formation events over the Mediterranean Basin from multiple ground-based and airborne measurements, Atmos. Chem. Phys., 17, 9567-9583, https://doi.org/10.5194/acp-17-9567-2017, 2017.

Boy, M., Hellmuth, O., Korhonen, H., Nilsson, E. D., ReVelle, D., Turnipseed, A., Arnold, F., and Kulmala, M.: MALTE - model to predict new aerosol formation in the lower troposphere, Atmos. Chem. Phys., 6, 4499-4517, https://doi.org/10.5194/acp-6-44992006, 2006.

Boy, M., Mogensen, D., Smolander, S., Zhou, L., Nieminen, T., Paasonen, P., Plass-Dülmer, C., Sipilä, M., Petäjä, T., Mauldin, L., Berresheim, H., and Kulmala, M.: Oxidation of $\mathrm{SO}_{2}$ by stabilized Criegee intermediate (sCI) radicals as a crucial source for atmospheric sulfuric acid concentrations, Atmos. Chem. Phys., 13, 3865-3879, https://doi.org/10.5194/acp-13-3865-2013, 2013.

Bzdek, B. R., Zordan, C. A., Pennington, M. R., Luther, G. W., and Johnston, M. V.: Quantitative Assessment of the Sulfuric Acid Contribution to New Particle Growth, Environ. Sci. Technol., 46, 4365-4373, https://doi.org/10.1021/es204556c, 2012.

Chen, X., Virkkula, A., Kerminen, V.-M., Manninen, H. E., Busetto, M., Lanconelli, C., Lupi, A., Vitale, V., Del Guasta, M., Grigioni, P., Väänänen, R., Duplissy, E.-M., Petäjä, T., and Kulmala, M.: Features in air ions measured by an air ion spectrometer (AIS) at Dome C, Atmos. Chem. Phys., 17, 13783-13800, https://doi.org/10.5194/acp-17-13783-2017, 2017.

Cusack, M., Pérez, N., Pey, J., Wiedensohler, A., Alastuey, A., and Querol, X.: Variability of sub-micrometer particle number size distributions and concentrations in the West- 
ern Mediterranean regional background, Tellus B, 65, 19243, https://doi.org/10.3402/tellusb.v65i0.19243, 2013.

Dall'Osto, M., Beddows, D. C. S., Asmi, A., Poulain, L., Hao, L., Freney, E., Allan, J D., Canagaratna, M., Crippa, M., Bianchi, F., de Leeuw, G., Eriksson, A., Swietlicki, E., Hansson, H C., Henzing, J S., Granier, C., Zemankova, K., Laj, P., Onasch, T., Prevot, A., Putaud, J P., Sellegri, K., Vidal, M., Virtanen, A., Simo, R, Worsnop, D., O’Dowd, C.,Kulmala, M., and Harrison, R. M.: Novel insights on new particle formation derived from a pan-european observing system, Sci. Rep., 8, 1482, https://doi.org/10.1038/s41598-017-17343-9, 2018.

Dal Maso, M., Kulmala, M., Riipinen, I., Wagner, R., Hussein, T., Aalto, P. P., and Lehtinen, K. E. J.: Formation and growth of fresh atmospheric aerosols: eight years of aerosol size distribution data from SMEAR II, Hyytiälä, Finland, Boreal Environ. Res., 10, 323-336, 2005.

Damian, V., Sandu, A., Damian, M., Potra, F., and Carmichael, G. R.: The kinetic preprocessor KPP-a software environment for solving chemical kinetics, Comput. Chem. Eng., 26, 1567-1579, https://doi.org/10.1016/S0098-1354(02)00128-X, 2002.

Daskalakis, N., Myriokefalitakis, S., and Kanakidou, M.: Sensitivity of tropospheric loads and lifetimes of short lived pollutants to fire emissions, Atmos. Chem. Phys., 15, 3543-3563, https://doi.org/10.5194/acp-15-3543-2015, 2015.

Daskalakis, N., Tsigaridis, K., Myriokefalitakis, S., Fanourgakis, G. S., and Kanakidou, M.: Large gain in air quality compared to an alternative anthropogenic emissions scenario, Atmos. Chem. Phys., 16, 9771-9784, https://doi.org/10.5194/acp16-9771-2016, 2016.

Debevec, C., Sauvage, S., Gros, V., Sellegri, K., Sciare, J., Pikridas, M., Stavroulas, I., Leonardis, T., Gaudion, V., Depelchin, L., Fronval, I., Sarda-Esteve, R., Baisnée, D., Bonsang, B., Savvides, C., Vrekoussis, M., and Locoge, N.: Driving parameters of biogenic volatile organic compounds and consequences on new particle formation observed at an eastern Mediterranean background site, Atmos. Chem. Phys., 18, 14297-14325, https://doi.org/10.5194/acp-18-14297-2018, 2018.

Dee, D. P., Uppala, S. M., Simmons, A. J., Berrisford, P., Poli, P., Kobayashi, S., and Vitart, F.: The ERA-Interim reanalysis: configuration and performance of the data assimilation system, Q. J. Roy. Meteor. Soc., 137, 553-597, https://doi.org/10.1002/qj.828, 2011.

Fotiadi, A., Hatzianastassiou, N., Drakakis, E., Matsoukas, C., Pavlakis, K. G., Hatzidimitriou, D., Gerasopoulos, E., Mihalopoulos, N., and Vardavas, I.: Aerosol physical and optical properties in the Eastern Mediterranean Basin, Crete, from Aerosol Robotic Network data, Atmos. Chem. Phys., 6, 53995413, https://doi.org/10.5194/acp-6-5399-2006, 2006.

Gordon, H., Kirkby, J., Baltensperger, U., Bianchi, F., Breitenlecher, M., Curtius, J., Dias, A., Dommen, J., Donahue, N. M., Dunne, E. M., Duplissy, J., Ehrhart, S., Flagan, R. C., Frege, C., Fuchs, C., Hansel, A., Hoyle, C. R., Kulmala, M., Kürten, A., Lehtipalo, K., Makhmutov, V., Molteni, U., Rissanen, M. P., Stozkhov, Y., Tröstl, J., Tsagkogeorgas, G., Wagner, R., Williamson, C., Wimmer, D., Winkler, P. M., Yan, C., and Carslaw, K. S.: Causes and importance of new particle formation in the present-day and preindustrial atmospheres, J. Geophys. Res.-Atmos., 122, 87398760, 2017.
Granier, C., Guenther, A., Lamarque, J., Mieville, A., Müller, J., Olivier, J., Orlando, J., Peters, J., Petron, G., Tyndall, G., and Wallens, S.: POET, a database of surface emissions of ozone precursors, available at: http://www.aero.jussieu.fr/projet/ ACCENT/POET.php (last access: 20 February 2019), 2005.

Hamed, A., Birmili, W., Joutsensaari, J., Mikkonen, S., Asmi, A., Wehner, B., Spindler, G., Jaatinen, A., Wiedensohler, A., Korhonen, H., Lehtinen, K. E. J., and Laaksonen, A.: Changes in the production rate of secondary aerosol particles in Central Europe in view of decreasing $\mathrm{SO}_{2}$ emissions between 1996 and 2006, Atmos. Chem. Phys., 10, 1071-1091, https://doi.org/10.5194/acp-10-1071-2010, 2010.

Hõrrak U., Salm J., and Tammet H.: Bursts of intermediate ions in atmospheric air, J. Geophys. Res., 103, 13909-13915, https://doi.org/10.1029/97JD01570, 1998.

Huang, X., Zhou, L., Ding, A., Qi, X., Nie, W., Wang, M., Chi, X., Petäjä, T., Kerminen, V.-M., Roldin, P., Rusanen, A., Kulmala, M., and Boy, M.: Comprehensive modelling study on observed new particle formation at the SORPES station in Nanjing, China, Atmos. Chem. Phys., 16, 2477-2492, https://doi.org/10.5194/acp-16-2477-2016, 2016.

Inness, A., Baier, F., Benedetti, A., Bouarar, I., Chabrillat, S., Clark, H., Clerbaux, C., Coheur, P., Engelen, R. J., Errera, Q., Flemming, J., George, M., Granier, C., Hadji-Lazaro, J., Huijnen, V., Hurtmans, D., Jones, L., Kaiser, J. W., Kapsomenakis, J., Lefever, K., Leitão, J., Razinger, M., Richter, A., Schultz, M. G., Simmons, A. J., Suttie, M., Stein, O., Thépaut, J.-N., Thouret, V., Vrekoussis, M., Zerefos, C., and the MACC team: The MACC reanalysis: an $8 \mathrm{yr}$ data set of atmospheric composition, Atmos. Chem. Phys., 13, 4073-4109, https://doi.org/10.5194/acp13-4073-2013, 2013.

Kalivitis, N., Birmili, W., Stock, M., Wehner, B., Massling, A., Wiedensohler, A., Gerasopoulos, E., and Mihalopoulos, N.: Particle size distributions in the Eastern Mediterranean troposphere, Atmos. Chem. Phys., 8, 6729-6738, https://doi.org/10.5194/acp8-6729-2008, 2008.

Kalivitis, N., Stavroulas, I., Bougiatioti, A., Kouvarakis, G., Gagné, S., Manninen, H. E., Kulmala, M., and Mihalopoulos, N.: Night-time enhanced atmospheric ion concentrations in the marine boundary layer, Atmos. Chem. Phys., 12, 3627-3638, https://doi.org/10.5194/acp-12-3627-2012, 2012.

Kalivitis, N., Kerminen, V.-M., Kouvarakis, G., Stavroulas, I., Bougiatioti, A., Nenes, A., Manninen, H. E., Petäjä, T., Kulmala, M., and Mihalopoulos, N.: Atmospheric new particle formation as a source of $\mathrm{CCN}$ in the eastern Mediterranean marine boundary layer, Atmos. Chem. Phys., 15, 9203-9215, https://doi.org/10.5194/acp-15-9203-2015, 2015.

Kalkavouras, P., Bossioli, E., Bezantakos, S., Bougiatioti, A., Kalivitis, N., Stavroulas, I., Kouvarakis, G., Protonotariou, A. P., Dandou, A., Biskos, G., Mihalopoulos, N., Nenes, A., and Tombrou, M.: New particle formation in the southern Aegean Sea during the Etesians: importance for $\mathrm{CCN}$ production and cloud droplet number, Atmos. Chem. Phys., 17, 175-192, https://doi.org/10.5194/acp-17-175-2017, 2017.

Kerminen, V.-M. and Kulmala, M.: Analytical formulae connecting the "real" and the "apparent" nucleation rate and the nuclei number concentration for atmospheric nucleation events, J. Aerosol Sci., 33, 609-622, 2002. 
Kerminen, V.-M., Paramonov, M., Anttila, T., Riipinen, I., Fountoukis, C., Korhonen, H., Asmi, E., Laakso, L., Lihavainen, H., Swietlicki, E., Svenningsson, B., Asmi, A., Pandis, S. N., Kulmala, M., and Petäjä, T.: Cloud condensation nuclei production associated with atmospheric nucleation: a synthesis based on existing literature and new results, Atmos. Chem. Phys., 12, 12037 12059, https://doi.org/10.5194/acp-12-12037-2012, 2012.

Kopanakis, I., Chatoutsidou, S. E., Torseth, K., Glytsos, T., and Lazaridis, M.: Particle number size distribution in the eastern Mediterranean: Formation and growth rates of ultrafine airborne atmospheric particles, Atmos. Environ., 77, 790-802, https://doi.org/10.1016/j.atmosenv.2013.05.066, 2013.

Korhonen, H., Lehtinen, K. E. J., and Kulmala, M.: Multicomponent aerosol dynamics model UHMA: model development and validation, Atmos. Chem. Phys., 4, 757-771, https://doi.org/10.5194/acp-4-757-2004, 2004.

Kulmala, M., Vehkamäki, H., Petäjä, T., Dal Maso, M., Lauri, A., Kerminen, V.-M., Birmili, W., and McMurry, P. H.: Formation and growth rates of ultrafine atmospheric particles: A review of observations, J. Aerosol Sci., 35, 143-176, 2004a.

Kulmala, M., Kerminen, V.-M., Anttila, T., Laaksonen, A., and O'Dowd, C. D.: Organic aerosol formation via sulphate cluster activation, J. Geophys. Res., 109, 4205, https://doi.org/10.1029/2003JD003961, 2004b.

Kulmala, M., Petäjä, T., Nieminen, T., Sipilä, M., Manninen, H. E., Lehtipalo, K., and Kerminen, V.-M.: Measurement of the nucleation of atmospheric aerosol particles, Nat. Protoc., 7, 1651, https://doi.org/10.1038/nprot.2012.091, 2012.

Kulmala, M., Petäjä, T., Ehn, M., Thornton, J., Sipilä, M., Worsnop, D. R., and Kerminen, V.-M.: Chemistry of atmospheric nucleation: On the recent advances on precursor characterization and atmospheric cluster composition in connection with atmospheric new particle formation, Annu. Rev. Phys. Chem., 65, 21-37, 2014.

Kulmala, M., Kerminen, V.-M., Petäjä, T., Ding, A. J., and Wang L.: Atmospheric gas-to-particle conversion: why NPF events are observed in megacities?, Faraday Discuss., 200, 271-288, https://doi.org/10.1039/c6fd00257a, 2017.

Kyrö, E.-M., Väänänen, R., Kerminen, V.-M., Virkkula, A., Petäjä, T., Asmi, A., Dal Maso, M., Nieminen, T., Juhola, S., Shcherbinin, A., Riipinen, I., Lehtipalo, K., Keronen, P., Aalto, P. P., Hari, P., and Kulmala, M.: Trends in new particle formation in eastern Lapland, Finland: effect of decreasing sulfur emissions from Kola Peninsula, Atmos. Chem. Phys., 14, 4383-4396, https://doi.org/10.5194/acp-14-4383-2014, 2014.

Lazaridis, M., Eleftheriadis, K., Smolik, J., Colbeck, I., Kallos, G., Drossinos, Y., Zdimal, V., Vecera, Z., Mihalopoulos, N., Mikuska, P., Bryant, C., Housiadas, C., Spyridaki, A., Astitha, M., and Havranek, V.: Dynamics of fine particles and photo-oxidants in the eastern Mediterranean (SUB-AERO), Atmos. Environ., 40, 6214-6228, https://doi.org/10.1016/j.atmosenv.2005.06.050, 2006.

Lehtipalo, K., Rondo, L., Kontkanen, J., Schobesberger, S., Jokinen, T., Sarnela, N., Kürten, A., Ehrhart, S., Franchin, A., Nieminen, T., Riccobono, F., Sipilä, M., Yli-Juuti, T., Duplissy, J., Adamov, A., Ahlm, L., Almeida, J., Amorim, A., Bianchi, F., Breitenlechner, M., Dommen, J., Downard, A. J., Dunne, E. M., Flagan, R. C., Guida, R., Hakala, J., Hansel, A., Jud, W., Kangasluoma, J., Kerminen, V.-M., Keskinen, H., Kim, J., Kirkby, J., Kupc, A.,
Kupiainen-Määttä, O., Laaksonen, A., Lawler, M. J., Leiminger, M., Mathot, S., Olenius, T., Ortega, I. K., Onnela, A., Petäjä, T., Praplan, A., Rissanen, M. P., Ruuskanen, T., Santos, F. D., Schallhart, S., Schnitzhofer, R., Simon, M., Smith, J. N., Tröstl, J., Tsagkogeorgas, G., Tomé, A., Vaattovaara, P., Vehkamäki, H., Vrtala, A. E., Wagner, P. E., Williamson, C., Wimmer, D., Winkler, P. M., Virtanen, A., Donahue, N. M., Carslaw, K. S., Baltensperger, U., Riipinen, I., Curtius, J., Worsnop, D. R., and Kulmala, M.: The effect of acid-base clustering and ions on the growth of atmospheric nano-particles, Nat. Commun., 7, 11594, https://doi.org/10.1038/ncomms11594, 2016.

Leino, K., Nieminen, T., Manninen, H. E., Petäjä, T., Kerminen, V.M., and Kulmala, M.: Intermediate ions as a strong indicator for new particle formation bursts in a boreal forest, Boreal Environ. Res., 21, 274-286, 2016.

Lelieveld, J., Berresheim, H., Borrmann, S., Crutzen, P., Dentener, F., Fischer, H., Feichter, J., Flatau, P., Heland, J., Holzinger, R., Korrmann, R., Lawrence, M., Levin, Z., Markowicz, K., Mihalopoulos, N., Minikin, A., Ramanathan, V., de Reus, M., Roelofs, G., Scheeren, H., Sciare, J., Schlager, H., Schultz, M., Siegmund, P., Steil, B., Stephanou, E., Stier, P., Traub, M., Warneke, C., Williams, J., and Ziereis, H.: Global air pollution crossroads over the Mediterranean, Science, 298, 794-799, https://doi.org/10.1126/science.1075457, 2002.

Levelt, P. F., van den Oord, G. H. J., Dobber, M. R., Malkki, A., Visser, H., de Vries, J., Stammes, P., Lundell, J. O. V., and Saari, H.: The Ozone Monitoring Instrument, IEEE T. Geosci. Remote, 44, 1093-1101, https://doi.org/10.1109/TGRS.2006.872333, 2006.

Madronich, S.: The atmosphere and UV-B radiation at ground level. Environmental UV Photobiology, Plenum Press, New York, 139, 1993.

Manninen, H. E., Nieminen, T., Asmi, E., Gagné, S., Häkkinen, S., Lehtipalo, K., Aalto, P., Vana, M., Mirme, A., Mirme, S., Hõrrak, U., Plass-Dülmer, C., Stange, G., Kiss, G., Hoffer, A., Töro, N., Moerman, M., Henzing, B., de Leeuw, G., Brinkenberg, M., Kouvarakis, G. N., Bougiatioti, A., Mihalopoulos, N., O'Dowd, C., Ceburnis, D., Arneth, A., Svenningsson, B., Swietlicki, E., Tarozzi, L., Decesari, S., Facchini, M. C., Birmili, W., Sonntag, A., Wiedensohler, A., Boulon, J., Sellegri, K., Laj, P., Gysel, M., Bukowiecki, N., Weingartner, E., Wehrle, G., Laaksonen, A., Hamed, A., Joutsensaari, J., Petäjä, T., Kerminen, V.-M., and Kulmala, M.: EUCAARI ion spectrometer measurements at 12 European sites - analysis of new particle formation events, Atmos. Chem. Phys., 10, 7907-7927, https://doi.org/10.5194/acp10-7907-2010, 2010.

Mihalopoulos, N., Stephanou, E., Kanakidou, M., Pilitsidis, S., and Bousquet, P.: Tropospheric aerosol ionic composition in the eastern Mediterranean region, Tellus B, 49, 314-326, 1997.

Mirme, A., Tamm, E., Mordas, G., Vana, M., Uin, J., Mirme, S., Bernotas, T., Laakso, L., Hirsikko, A., and Kulmala, M.: A widerange multi-channel Air Ion Spectrometer, Boreal Environ. Res., 12, 247-264, 2007.

Mogensen, D., Gierens, R., Crowley, J. N., Keronen, P., Smolander, S., Sogachev, A., Nölscher, A. C., Zhou, L., Kulmala, M., Tang, M. J., Williams, J., and Boy, M.: Simulations of atmospheric OH, $\mathrm{O}_{3}$ and $\mathrm{NO}_{3}$ reactivities within and above the boreal forest, Atmos. Chem. Phys., 15, 3909-3932, https://doi.org/10.5194/acp15-3909-2015, 2015. 
Myriokefalitakis, S., Vignati, E., Tsigaridis, K., Papadimas, C., Sciare, J., Mihalopoulos, N., Facchini, M. C., Rinaldi, M., Dentener, F. J., Ceburnis, D., Hatzianastasiou, N., O’Dowd, C. D., van Weele, M., and Kanakidou, M.: Global modelling of the oceanic source of organic aerosols, Adv. Meteorol., 2010, 939171, https://doi.org/10.1155/2010/939171, 2010.

Myriokefalitakis S., Daskalakis, N., Fanourgakis, G. S., Voulgarakis, A., Krol, M. C., Aan de Brugh, J. M. J., and Kanakidou, M.: Pollution over the Mediterranean Basin: The Importance of Long-Range Transport on ozone and carbon monoxide, Sci. Total Environ., 40, 563-564, 2016.

Nieminen, T., Asmi, A., Dal Maso, M., Aalto, P. P., Keronen, P., Petäjä, T., Kulmala, M., and Kerminen, V.-M.: Trends in atmospheric new-particle formation: 16 years of observations in a boreal-forest environment, Boreal Environ. Res., 19, 191-214, 2014.

O’Dowd, C. D., Hämeri, K., Mäkelä, J. M., Pirjola, L., Kulmala, M., Jennings, S. G., Berresheim, H., Hansson, H.-C., de Leeuw, G., Kunz, G. J., Allen, A. G., Hewitt, C. N., Jackson, A., Viisanen, Y., and Hoffmann, T.: A dedicated study of New Particle Formation and Fate in the Coastal Environment (PARFORCE): Overview of objectives and achievements, J. Geophys. Res., 107, 8108, https://doi.org/10.1029/2001jd000555, 2002.

Paraskevopoulou, D., Liakakou, E., Gerasopoulos, E., and Mihalopoulos, N.: Sources of atmospheric aerosol from longterm measurements (5 years) of chemical composition in Athens, Greece, Sci. Total Environ., 527-528, 165-178, https://doi.org/10.1016/J.SCITOTENV.2015.04.022, 2015.

Petäjä, T., Kerminen, V.-M., Dal Maso, M., Junninen, H., Koponen, I. K., Hussein, T., Aalto, P. P., Andronopoulos, S., Robin, D., Hämeri, K., Bartzis, J. G., and Kulmala, M.: Sub-micron atmospheric aerosols in the surroundings of Marseille and Athens: physical characterization and new particle formation, Atmos. Chem. Phys., 7, 2705-2720, https://doi.org/10.5194/acp-7-27052007, 2007.

Pikridas, M., Riipinen, I., Hildebrandt, L., Kostenidou, E., Manninen, H., Mihalopoulos, N., Kalivitis, N., Burkhart, J., Stohl, A., Kulmala, M., and Pandis, S. N.: NPF at a remote site in the eastern Mediterranean, J. Geophys. Res., 117, D12205, https://doi.org/10.1029/2012JD017570, 2012.

Salimi, F., Rahman, Md. M., Clifford, S., Ristovski, Z., and Morawska, L.: Nocturnal new particle formation events in urban environments, Atmos. Chem. Phys., 17, 521-530, https://doi.org/10.5194/acp-17-521-2017, 2017.

Sciare, J., Bardouki, H., Moulin, C., and Mihalopoulos, N.: Aerosol sources and their contribution to the chemical composition of aerosols in the Eastern Mediterranean Sea during summertime, Atmos. Chem. Phys., 3, 291-302, https://doi.org/10.5194/acp-3291-2003, 2003.

Siakavaras, D., Samara, C., Petrakakis, M., and Biskos, G.: Nucleation events at a coastal city during the warm period: Kerbside versus urban background measurements, Atmos. Environ., 140, 60-68, https://doi.org/10.1016/j.atmosenv.2016.05.054, 2016.

Spracklen, D. V., Carslaw, K. S., Kulmala, M., Kerminen, V.-M., Mann, G. W., and Sihto, S.-L.: The contribution of boundary layer nucleation events to total particle concentrations on regional and global scales, Atmos. Chem. Phys., 6, 5631-5648, https://doi.org/10.5194/acp-6-5631-2006, 2006.
Stein, A. F., Draxler, R. R, Rolph, G. D., Stunder, B. J. B., Cohen, M. D., and Ngan, F.: NOAA's HYSPLIT atmospheric transport and dispersion modeling system, B. Am. Meteorol. Soc., 96, 2059-2077, https://doi.org/10.1175/BAMS-D-14$00110.1,2015$.

Tammet, H., Komsaare, K., and Hõrrak, U.: Intermediate ions in the atmosphere, Atmos. Res., 135-136, 263-273, https://doi.org/10.1016/j.atmosres.2012.09.009, 2014.

Tröstl, J., Chuang, W. K., Gordon, H., Heinritzi, M., Yan, C., Molteni, U., Ahlm, L., Frege, C., Bianchi, F., Wagner, R. and Simon, M., Lehtipalo, K., Williamson, C., Craven, J. S., Duplissy, J., Adamov, A., Almeida, J., Bernhammer, A.-K., Breitenlechner, M., Brilke, S., Dias, A., Ehrhart, S., Flagan, R. C., Franchin, A., Fuchs, C., Guida, R., Gysel, M., Hansel, A., Hoyle, C. R., Jokinen, T., Junninen, H., Kangasluoma, J., Keskinen, H., Kim, J., Krapf, M., Kürten, A., Laaksonen, A., Lawler, M., Leiminger, M., Mathot, S., Möhler, O., Nieminen, T., Onnela, A., Petäjä, T., Piel, F. M., Miettinen, P., Rissanen, M. P., Rondo, L., Sarnela, N., Schobesberger, S., Sengupta, K., Sipilä, M., Smith, J. N., Steiner, G., Tomè, A., Virtanen, A., Wagner, A. C., Weingartner, E., Wimmer, D., Winkler, P. M., Ye, P., Carslaw, K. S., Curtius, J., Dommen, J., Kirkby, J., Kulmala, M., Riipinen, I., Worsnop, D. R., Donahue, N. M., and Baltensperger, U.: The role of low-volatility organic compounds in initial particle growth in the atmosphere, Nature, 533, 527-531, 2016.

Tzitzikalaki, E., Kalivitis, N., Kouvarakis, G., Daskalakis, N., Kerminen, V.-M., Mihalopoulos, N., Boy, M., and Kanakidou, M.: Simulations of New Particle Formation and Growth Processes at eastern Mediterranean, with the MALTE-Box Model, in: Perspectives on Atmospheric Sciences, edited by: Karacostas, T., Bais, A., and Nastos, P. T., 933-939, Springer International Publishing, Cham, Switzerland, 2017.

Wang, Z., Wu, Z., Yue, D., Shang, D., Guo, S., Sun, J., Ding, A., Wang, L., Jiang, J., Guo, H., Gao, J., Cheung, H. C., Morawska, L., Keywood, M., and Hu, M.: New particle formation in China: Current knowledge and further directions, Sci. Total Environ., 577, 258-266, https://doi.org/10.1016/j.scitotenv.2016.10.177, 2017.

Wiedensohler, A., Birmili, W., Nowak, A., Sonntag, A., Weinhold, K., Merkel, M., Wehner, B., Tuch, T., Pfeifer, S., Fiebig, M., Fjäraa, A. M., Asmi, E., Sellegri, K., Depuy, R., Venzac, H., Villani, P., Laj, P., Aalto, P., Ogren, J. A., Swietlicki, E., Williams, P., Roldin, P., Quincey, P., Hüglin, C., Fierz-Schmidhauser, R., Gysel, M., Weingartner, E., Riccobono, F., Santos, S., Grüning, C., Faloon, K., Beddows, D., Harrison, R., Monahan, C., Jennings, S. G., O’Dowd, C. D., Marinoni, A., Horn, H.-G., Keck, L., Jiang, J., Scheckman, J., McMurry, P. H., Deng, Z., Zhao, C. S., Moerman, M., Henzing, B., de Leeuw, G., Löschau, G., and Bastian, S.: Mobility particle size spectrometers: harmonization of technical standards and data structure to facilitate high quality long-term observations of atmospheric particle number size distributions, Atmos. Meas. Tech., 5, 657-685, https://doi.org/10.5194/amt-5-657-2012, 2012.

Yli-Juuti, T., Riipinen, N., Aalto, P. P., Nieminen, T., Maenhaut, W., Janssens, I. A., Claeys, M., Salma, I., Ocskay, R., Hoffer, A., Lmre, K., and Kulmala, M.: Characteristics of new particle formation events and cluster ions at K-puszta, Hungary, Boreal Environ. Res., 14, 683-698, 2009. 